\title{
Illk Yetişkinlik Dönemindeki Bireylerde Dua ve Başa Çıkma Tarzları Arasındaki İlişkinin İncelenmesi*
}

\section{Investigation of the Relationship between Prayer and Coping Styles in the Early Adulthood}

\author{
Yunus Emre TEMiz \\ Arş. Gör., Sakarya Üniversitesi Illahiyat Fakültesi, Din Psikolojisi Anabilim Dalı, \\ Research Assistant, Sakarya University, Faculty of Theology, Department of Psychology of Religion \\ Serdivan/Sakarya, Turkey \\ ytemiz@sakarya.edu.tr \\ orcid.org/0000-0002-0663-8940
}

\author{
Makale Bilgisi / Article Information \\ $\begin{array}{ll}\text { Makale Türü / Article Types } & \text { : Araştırma Makalesi / Research Article } \\ \text { Geliş Tarihi / Received } & : 9 \text { Nisan / April } 2019 \\ \text { Kabul Tarihi / Accepted } & : 31 \text { Mayıs / May } 2019 \\ \text { Yayın Tarihi / Published } & : 15 \text { Haziran / June } 2019 \\ \text { Yayın Sezonu / Pub Date Season } & \text { : Haziran / June } \\ \text { Cilt / Volume: 6 Sayı / Issue: } 1 \text { - Sayfa / Pages: 177-206 }\end{array}$
}

Atıf / Cite as

Temiz, Yunus Emre. "ilk Yetişkinlik Dönemindeki Bireylerde Dua ve Başa Çıkma Tarzları Arasındaki Illişkinin Incelenmesi". Bülent Ecevit Üniversitesi Ilahiyat Fakültesi Dergisi, 6/1 (2019): 177-206.

Doi: $10.33460 /$ beuifd. 551350

İntihal / Plagiarism

Bu makale, en az iki hakem tarafından incelendi ve intihal içermediği teyit edildi.

This article has been reviewed by at least two referees and scanned via a plagiarism software.

Yayın Hakkı / Copyright ${ }^{\circ}$

Zonguldak Bülent Ecevit Üniversitesi, İlahiyat Fakültesi tarafından yayınlanmıștır. Tüm hakları saklıdır.

Published by Zonguldak Bulent Ecevit University, Faculty of Theology, Zonguldak, Turkey. All rights reserved.

Öz: Dini inançlar veya davranışlar içerisinde dua, dinin ruhu ve özü olarak nitelendirilmektedir. Bireylerin yaşamlarında karşılaştıkları problemleri aşmada en büyük dini desteklerden biri olan dua, bu araştırmada bir dini başa çıkma yöntemi olarak ele alınmaktadır. Bu çerçevede araştırmada, duanın değişik göstergeleri ile başa çıkmanın farklı boyutları arasında ne tür bir bağlantının olduğu ve bu ilişkinin farklı demografik değişkenlere bağlı olarak nasıl bir değişme gösterdiği incelenmektedir. Ayrıca duanın bir dini başa çıkma yöntemi olarak nitelendirilmesinden dolayı dindarlık ile dua arasındaki ilişki ve etkileşim üzerinde de durulmaktadır. Bu kapsamda çalışmada, korelasyonel araştırma modeline uygun olarak dua, başa çıkma tarzları ve dindarlık arasındaki ilişki ve etkileşim incelenmektedir. Araştırmanın örneklemini ilk yetişkinlik çağında bulunan 415 katılımcı oluşturmaktadır. Araştırma sonucunda cinsiyet, yaş, medeni durum, sosyal çevre ve eğitim durumu dua üzerinde anlamlı bir farklılığa sebep

* Bu makale, yazarın “Yetişkinlerde Dini Başa Çıkma Yöntemi Olarak Dua” başlıklı yüksek lisans tezinden üretilmiştir. 
olmazken, gelir durumunun anlamlı farklılığa sebep olduğu görülmüştür. Araştırma sonuçlarına göre dindarlık, duanın açıklanmasında önemli bir faktör olarak ortaya çıkmıştır. Ayrıca herhangi bir sebeple Tanrı'ya yönelerek ona yalvaran, ondan yardım dileyen, ona şükreden ve duanın pozitif etkilerini yaşayan bireylerle sorunlar karşısında yılmadan mücadele eden, aktif bir şekilde sorunların üstesinden gelmek için uğraşan bireylerin puanları arasında pozitif yönde ilişkilerin varlığı tespit edilmiştir. Yine duanın manevi hoşnutsuzluk boyutu ile duygusal odaklı başa çıkma tarzları arasında negatif bir ilişki belirlenmiştir. Sonuç olarak başa çıkmanın farklı boyutlarıyla duanın değişik göstergelerinin birbirleriyle ilişkili olduğu görülmüştür.

Anahtar Kelimeler: Din Psikolojisi, Dua, Başa Çıkma, Dini Başa Çıkma, Dindarlık, Ilk Yetişkinlik

Abstract: In religious beliefs or behaviours, prayer is described as the spirit and essence of religion. Prayer, one of the greatest religious supports in overcoming the problems faced by individuals in their lives is considered as a religious coping method in this research. In this context, this study focuses on different varieties of prayer in relation to different coping styles in young adults with regard to some demographic variables. In addition, the relationship between prayer and religiosity is emphasized as prayer is considered a religious coping method. In this context, the relationship between prayer, coping styles and religiosity is examined in accordance with the correlational research model. The sample of the study consists of 415 people in the early adulthood. According to the study findings, only the income situation from demographic variables caused a significant difference on prayer. Religiosity also emerged as an important factor in explaining prayer. A positive correlation was also found between problem-oriented coping styles and the sub-dimensions of prayer scale. Furthermore, there is a negative relation between spiritual discontent and emotion-focused coping styles. We are finally led to the conclusion that certain varieties of prayer are connected to certain styles of coping.

Keywords: Psychology of Religion, Prayer, Religious Coping, Religiosity, Adulthood

\section{GíRiş}

Anlam, bireyin hayata tutunmasını sağlar. Anlam ve kontrolün tehdit edildiği durumlarda, problemlerin üstesinden gelmek için birey, başa çıkma sürecine girer. Birey bu süreçte çeşitli unsurlardan yardım alır. Böyle bir süreçte en önde gelen yardımcı unsurlar dini inanç ve değerlerdir. İnsanların sıkıntılı durumlarda problemlerinin üstesinden gelmek için dini referans olarak serdettikleri gayret ve faaliyetler dini başa çıkma olarak adlandırılmaktadır. Bu gayret ve faaliyetler içerisinde belki de en belirgin olanı, dinin ruhu ve özü olarak nitelendirilen dua'dır. Dini başa çıkma sürecinde tevazu, şükür, affetme, sabır, itaat ve tevekkül gibi birçok unsur olmakla beraber dua, problemlerin çözümünde sıklıkla ve 
öncelikle başvurulan bir dini etkinliktir ${ }^{1}$. Bireylerin yaşamlarında karşılaştıkları problemleri aşmada en büyük dini desteklerden biri olan dua, bu araştırmada bir dini başa çıkma yöntemi olarak ele alınmıştır.

Bu çalışmanın temel amacı, genç yetişkinlik döneminde, başa çıkmanın farklı boyutları ile duanın değişik göstergeleri arasında ne tür bir bağlantının olduğu ve bu ilişkinin farklı demografik değişkenlere bağlı olarak nasıl bir değişme gösterdiğini incelemektir. Genç yetişkin bireylerin karşılaştıkları problemlerle baş etmede dini referans alarak başvurdukları etkinliklerden biri olan dua ile başa çıkma tarzları aralarında nasıl bir ilişkinin olduğunun araştırılması, bireylerin duygu, düşünce ve davranışları üzerinde etkiye sahip olan dinin anlam ve öneminin daha iyi bir şekilde anlaşılmasını sağlayacaktır. Ayrıca duanın bir dini başa çıkma yöntemi olarak nitelendirilmesinden dolayı dinsel eğilim ile dua arasındaki ilişki ve etkileşim üzerinde de durulmaktadır. "Bir dini başa çıkma etkinliği olan dua ile diğer başa çıkma etkinlikleri arasında nasıl bir ilişki vardır?" sorusu temelinde şekillenen çalışmada, ilk olarak dua, başa çıkma ve dini başa çıkma kavramları ele alınmaktadır. İkinci olarak ise değişkenler arasındaki ilişkiyi tespit etmek için yürütülen araştırmaya ait istatistiksel verilere yer verilmektedir. Son olarak ise bulguların yorumlandığı ve değerlendirildiği sonuç kısmı ile araştırma tamamlanmaktadır.

\section{Dua}

Dua sözcüğü, kişinin kendisinden çıkan bir ses veya sözle bir şeyi kendisine meylettirmesi² anlamına gelen deave (دعو) fiilinin masdarı olup, Allah'a yalvarmak ${ }^{3}$, nida $^{4}$, isimlendirme ${ }^{5}$, istemek ${ }^{6}$, istiğase ${ }^{7}$ (yardım istemek), bir şeye çağırmak ${ }^{8}$, ibadet $^{9}$, yönlendirmek ${ }^{10}$ ve dâvet ${ }^{11}$ gibi anlamlar içermektedir. Küçükten büyüğe, aşağıdan yukarıya vâki olan talep ve niyaz, anlamında isim olarak da kullanılan dua kelimesi ayrıca Allah'a sunulacak talepleri sözlü ve yazılı olarak dile getiren metinler için de kullanılır².

1 Kenneth I. Pargament, The Psychology of Religion and Coping Theory, Research, Practice (New York: The Guilford Press, 1997), 178; Ali Ayten, Tanrı'ya Sığınmak Dini Başa Çıkma Üzerine Psiko-sosyal Bir Araştırma (İstanbul: İz Yayıncılık, 2012), 42.

2 İbn Fâris, "D'av", Mu'cemu mekâyî̀su'l-luġa, thk. Abdusselâm Muhammed Harun (Beyrut: Dâru'I-Fikr, 1979), 2: 279.

3 Muhammed b. Ya'kûb Fîrûzâbâdî, "D'av", el-Kâmûsu'I-muhît (Mısır: Matbaatu'I-Emîrîyye, 1979), 4: 321; Muhammed Murtazâ Zebîdî, "D'av", Tâcü'l-arûs min Cevâhiri'l-kâmûs (Kuveyt: Turâsu'l-Arabi, 1965), 38: 46.

4 Râġıb el-Ișfahânî, “D'av”, el-Müfredât fí garîbi'l-Kur'ân, thk. Muhammed Seyyid Keylânî (Beyrut: Daru'I-Ma'rife, ts.), 169-170.

5 İșfahânî, “D’av”, el-Müfredât, 169-170; Zebîdî, “D'av", Tâcü'I-arûs min Cevâhiri'l-kâmûs, 38: 47.

6 İșfahânî,“"D'av", el-Müfredât, 169-170.

7 ỉbn Manz̦ûr, “D’av", Lisânu'l-arab (Beyrut: Dâru Sâdr, ts.), 14: 257-263; el-ìșfahânî, “D'av”, el-Müfredât, 169-170.

8 İ̦fahânî, “D'av", el-Müfredât, 169-170.

9 İbn Manzûr, "D'av", Lisânu'l-Arab, 14: 257-263.

10 Zebîdî, "D'av", Tâcü'l-arûs min Cevâhiri'l-kâmûs, 38: 47.

11 Fîrûzâbâdî, "D'av", el-Kâmûsu'l-muhît, 4: 322.

12 Osman Cilacı, "Duâ", Türkiye Diyanet Vakfı İlâm Ansiklopedisi (İstanbul: Türkiye Diyanet Vakfı Yayınları, 1994), 9: 529. 
Sözlük anlamları göz önünde bulundurulduğunda genel olarak duanın, küçükten büyüğe, aşağıdan yukarıya doğru bir talep, bir yalvarma yakarma anlamında kullanıldığı göze çarpmaktadır. Özel olarak İslami literatürde dua, Allah'ın yüceliği karşısında kulun zayıflı̆ını itiraf etmesini, sevgi ve tazim duyguları içinde lütuf ve yardımını dilemesini ifade eder ${ }^{13}$. İbn Manzur ${ }^{14}$ da kavram olarak duanın, ilk sırada Allah'ın birlik ve yüceliğini dile getirmek, ikinci sırada ise O'ndan maddi ve manevi lütuf ve nimetler ihsan etmesini istemek şeklinde iki anlamı olduğunu ifade etmiştir.

Psikolog James ${ }^{15}$ ise duayı, dinin ruhu ve özü olarak tanımlamıştır. Benzer şekilde Heiler ${ }^{16}$ de duanın dinin kalbi ve merkezi olduğunu ifade etmiştir. Bu ifadeler açıkça göstermektedir ki dua din içerisinde merkezi bir yer ve öneme sahiptir.

Duanın önde gelen özelliklerinden birinin Tanrıdan istek ve talepte bulunma olduğu söylenebilir. Nitekim İslami literatürde duayı Cilacı ${ }^{17}$ kulun bütün benliği ile yüce yaratana yönelerek ondan istek ve dilekte bulunması anlamında dini bir terim ve bu amaçla icra edilen bir ibadet şekli olarak belirtmiştir. Özetle ibadetin öz öğesi olan dua, kutsalın yardımını sağlamak, merhametini celp etmek ve bunları harekete geçirmek için bireyin içinde bulunduğu hale göre o anki seslenişidir. Bu kapsamda dua, birey ve yaratıcı arasında bir diyalog anlamı taşımaktadır.

\subsection{Dua-İnsan İlişkisi}

Dua bir yönü ile insanın kutsal ile iletişim kurmasıdır. Bu kapsamda Toshihiko Izutsu $^{18}$ duanın, birey ile yaratıcısı arasında dolaylı bir diyalog olduğuna değinmiştir. O, Kur'an'daki vahiy kavramını tahlil ederken onun Allah'la insan arasında cereyan eden, yukarıdan aşağıya, Allah'tan insana doğru olan bir çeşit özel konuşma olduğunu söyler. Burada Allah, kendi kelimelerini insana yöneltir. Lakin Allah ile insan arasındaki bu lisani münasebet tek yönlü değildir. Yani birey bu münasebette daima pasif kalmaz, bazen o da Allah ile sözlü bir ilişki başlatır. Nihayetinde bu ilişkinin neticesinde öyle bir olay doğar ki bu, yapı bakımından vahye benzer, ancak bunda konuşma doğrultusu yukarıdan aşağıya değil, aşağıdan yukarıya doğrudur. Vahiy gibi bu da olağan üstü şartlar altında ve özel bir biçimde meydana gelir. Normal olarak insan doğrudan doğruya Allah'a hitap etme vasıtasına sahip değildir. Normal kelime alışverişi olabilmesi için iki taraf arasında ontolojik eşitlik bulunmalıdır. Ancak insan zihni çeşitli durumlarda günlük durumun üstüne çıkar, gerilir ve kırılma derecesine varır. Böylece insan, Tanrıya doğrudan doğruya söz söyleme noktasına varmış olur. Dolayısı ile

13 Cilacı, “Duâ", 9: 529.

14 İbn Manz̦ûr, “D’av", Lisânu'l-Arab, 14: 257-263.

15 William James, The Varieties of Religious Exerience: A Study in Human Nature. (London: Fontana Library, 1962$), 444$.

16 F. Heiler, Prayer A Study in the History and Psychology of Religion (New York: Oxford University Press, 1932 ), 362.

17 Cilacl, “Duâ", 9: 529.

18 Toshihiko Izutsu, Kur'ân'da Allah ve Insan, trc. S. Ateş (Ankara: Ankara Üniversitesi Basımevi, 1975$), 182$. 
Izutsu'ya göre dua, olağan üstü durum içinde geçen böyle bir konuşma olayıdır. Douglas ise bu türlü iletişime dolaylı olarak değinerek duanın Allah'ın durmadan taşan sevgi ve alakasına kulun verdiği bir cevap olduğunu ifade etmiştir ${ }^{19}$. Marinier ${ }^{20}$ kriz anları diye nitelendirilebilecek buhranlı durumlarda, sıkıntı anında, acizlik veya hastalık durumunda, bir tehlike veya suçluluk hissine cevap olarak, insanların duaya yöneldiğini belirtir ve bu durumlarda meydana gelen şeylere karşı koymak için normal şuurun yetersiz olduğunu da sözlerine ekler.

İnsanı, insan zihnini bu duruma sokan, böylesine bir yoğunlaşmayı meydana getiren faktörler çeşitlidir. Bireylerin dua etme vakitleri incelendiği zaman, insanların büyükçoğunluğunun, genelliklemahrumiyet veçaresizlikzamanlarında Tanrı'ya yöneldikleri tespit edilmiştir. Bu noktada Kılıç ${ }^{21}$ insanların daha çok aciz ve çaresiz kaldıkları zaman duaya yöneldiklerini, rahatlık zamanlarından ise duanın keyfiyet ve kemiyetinde azalma olduğunu ifade etmiştir. 11-18 yaş arası öğrenciler üzerinde yapılan bir araştırmada, Allah'a dua etmelerine sebep olarak \%41'i manevi sorunları, \%15 i maddi problemleri, \%11'i mutluluk anlarını, \%7'si tabiatın güzelliğini saymışlardır ${ }^{22}$. Hökelekli²3 de gençlerin duaya yönelişinde gelecek endişesi, günahlarını affettirme ümidi, sınavlarda başarılı olma arzusu, sevilen birinin ölümünden duyulan üzüntü, hastalık ve tehlikeli durumlarda yardım ve güvenlik isteği gibi sebeplerin büyük önem arz etiğine işaret etmiştir. Horozcu ise sağlık, hayatta başarı, bitkiler, yağmur, çocuk sahibi olmak ve diğer canlılar için duaya başvurulduğunu belirtmektedir ${ }^{24}$.

\subsection{Duanın Mekânı ve Zamanı}

Duanın kabulü için şart olmamakla birlikte uygulamada bazı şekli unsurlar gözetilmiştir. Bunlar daha çok zaman, mekân ve dua şekilleri ile ilgilidir. Dua her yerde yapılabildiği halde tarih boyunca çeşitli dinlerde dua için özel mekânlar tespit edilmiş veya buralarda dua etmenin daha etkili olacağı düşünülmüştür. Dua ve ibadetlerin cemaatle yerine getirilmesi amacıyla yapılan mabetlerin dışında, ilahi kudretin muhtelif vesilelerle tecelli ettiği yüksek yerler, kayalar ve dağlar bazı ağaçların çevresi, gibi mekânlar da dua yeri olarak rağbet görmüştür ${ }^{25}$. Yani dua etmek için mekân ve zaman konusunda bir kısıtlama olmamakla birlikte ${ }^{26}$, belli

19 Steere V. Douglas, Duâ ve ibadet, (İstanbul: Akın Basımevi, 1941), 12, akt. Selâhattin Parladır, "Dua: Varlığın Özü, İbadetin Ruhu", İslam'a Giriș (Ankara: Diyanet İșleri Bașkanlığı Yayınları, 2007), 330.

20 Pierre Marinier, Dua Üzerine Düşünceler (Psikofizyolojik sebepleri ve sonuçları), trc. Sıddık Kılıç (İzmir: Nil Yayınları, 1991), 27.

21 Ahmet Faruk Kılıı̧, "Psiko-Sosyal Faktörler Açısından Atatürk ve Din", Sakarya Üniversitesi Illahiyat Fakültesi Dergisi 2 (2000): 243.

22 Antonie Vergote, Din, İnanç ve Inançsızlık, trc. V. Uysal (İstanbul: Marmara Üniversitesi Illahiyat Fakültesi Vakfı Yayınları, 1999), 47.

23 Hayati Hökelekli, Ergenlik Çağı Gençlerin Dini Gelişimi (1983), 87

24 Ümit Horozcu, Din Psikolojisi Açısından Dünyevi İstek Duaları (Doktora Tezi, İstanbul Üniversitesi 2010), 114-184.

25 Cilacl, "Duâ", 9: 529.

26 M. Doğan Karacoşkun, "Okul Öncesi Dönem Çocuklarında Dua”, Cumhuriyet Üniversitesi Illahiyat Fakültesi Dergisi 9/1 (2005): 103. 
mekân ve vakitler, kişinin uygun ve verimli dua etmesi için psikolojik toparlanma bakımından zaman zaman olumlu etkiler yapabilmektedirler ${ }^{27}$. Nitekim dua ruhsal bir hal olduğuna göre, insana sükûn veren ve kalp huzuru getiren şartların elverişliliğinin önemli olduğuna dikkat çekilmiştir ${ }^{28}$.

\subsection{Duanın Türleri}

Dua evrensel bir tutum ve davranış olduğu için çok farklı yönde çeşitlilik göstermektedir. Duada, dini, coğrafi ve kültürel farklılıklardan bahsedilebileceği gibi, dua pratiğinin biçimi veya içeriği açısından da duanın türlerinden bahsedilebilir. Bazı dualarımız şükranlarımızın ifadesi iken bazı dualarımız isteklerimizin ifadesidir ${ }^{29}$. Dinlerde dua, muhteva, şekil ve anlatım biçimine göre bazı türlere ayrılır. Asıl ve en yaygın olanı yalvarıp yakarmaktır. Bu tür duada insan bir kötülükten kurtulmayı veya bir iyiliğe kavuşmayı diler. Bahsi geçtiği üzere duanın diğer bir türü de hamd ve şükür etmektir. Bu ise kabul ettiği bir istek ve dilekten dolayı Tanrı'yı üstün vasıflarını sayarak yüceltmektir. Ayrıca hamd ve şükür genelde yalvarış duasının başında yer alır ${ }^{30}$. Yine dua; söz ve kalple, fiil ve hâl ile de yapılır. Dua, "hayır dua" ve "beddua" şeklinde olabilir. Dua, insanın kendisine veya başkasına yönelik olabilir. İçeriği açısından dua, maddi veya manevi isteklere, dünyevi ve uhrevi isteklere yönelik olabilir ${ }^{31}$.

İbn Manzur², Allah'ın birliğini dile getirme ve O'nu övgü ile anma, Allah'tan af, merhamet gibi manevi isteklerde bulunma ve son olarak da kendisinden dünyevi nimetler isteme tarzında duanın üç şeklinin bulunduğunu belirtmiştir. Ayrıca O, genellikle "Yâ Rabbi, Allah'ım" gibi hitap ve çağrı ifadeleri ile başlayan veya Allah'ı övgü ile anan her sözün -içinde bir dilek ve istek bulunmasa da- dua olduğuna işaret etmiştir. Poloma ve Pendleton ise duayı, derin düşünce anlamında dua, dini pratik olarak dua, istekte bulunma anlamında dua ve konuşma diline ait dua olarak dörtlü bir sınıflamaya tabi tutmuşlardır ${ }^{33}$.

\subsection{Fiziki ve Psikolojik Yönden Dua'nın Etkileri}

Tanrı'ya dua aracılığı ile yaklaşan insanoğlunun ${ }^{34}$ icra ettiği dini işlemlerdeki maksat, Tanrıyı etkilemektir ${ }^{35}$. Kierkegard, ancak bu etkilemede dua etmenin

27 Adil Bebek, Din ve Düşünce Açısından Dua (İstanbul: Rağbet Yayınları, 1998), 35.

28 Hüseyin Peker, Din Psikolojisi, 7. Baskı (İstanbul: Çamlıca Yayınları, 2011), 129; Carrel, Duâ, 22.

29 Asım Yapıcı, "Güdü ve İçerik Açısından Çocuk Duaları ve Dualara yansıyan Sorunlar", Çukurova Üniversitesi Illahiyat Fakültesi Dergisi 5/2 (2005): 60-65; Ahmet Albayrak, Gençlerde Dua Psikolojisi (İstanbul: Düşünce Kitabevi Yayınları, 2013), 56; Abdullah Dağcı, “Amaçsal Açıdan Dua Türleri: Din Psikolojisi Bağlamında Tümevarımsal Bir Yaklaşım Denemesi", Eskişehir Osmangazi Üniversitesi Illahiyat Fakültesi Dergisi, 5/8 (2018): 87-120.

30 Cilacı, "Duâ", 9: 529; bkz, Horozcu, Din Psikolojisi Açısından Dünyevi İstek Duaları, 49-53.

31 İsmail Karagöz, "Duanın Anlamı ve Önemi, Çeşitleri, Usulü, Âdâbı ve İnsan Hayatına Etkisi", Dualar, ed. İsmail Karagöz (Ankara: Diyanet İşleri Başkanlığı Yayınları, 2011), 38.

32 İbn Manz̦ûr, "D’av", Lisânu'l-Arab, 14: 257-263.

33 M. M. Poloma - B. F. Pendleton, "Religious Experiences, Evangelism, and Institutional Growth within the Assemblies of God", Journal for the Scientific Study of Religion" 28 (1991), akt. Michael Argyle, "ibadet ve Dua”, trc. Mustafa Koç, Erciyes Üniversitesi Sosyal Bilimler Enstitüsü Dergisi 2/21 (2006): 330.

34 Carrel, Duâ, 37.

35 Argyle, Psychology and Religion: An Introduction, 87. 
Tanrı'yı değil, dua edeni değiştireceğini söyler ${ }^{36}$. Uygun şartlar altında duanın pozitif etkisinin mutlak ve kesin olduğu, kişide hem bedensel hem de ruhsal değişikliklere yol açtığı, bu etkilerin öznel olduğu kadar nesnel verilerle de doğrulandığı çok sayıda araştırmacı tarafından belirtilmiş ve ortaya konmuştur ${ }^{37}$. Gerçekleştirilen diğer bazı araştırmalarda ${ }^{38}$ ise duanın pozitif etkilerinin yanı sıra az da olsa negatif etkilerinin varlığı da tespit edilmiştir.

\section{Başa Çıkmanın Kavramsallaştırılması}

Başa çıkma konusu literatürde daha ziyade stres kavramı ile ilişkili olarak ele alınmakta ve açıklanmaktadır. Strese yol açan durumların yarattığı duygular ve psikolojik uyarılma son derece rahatsız edicidir ve bu rahatsızlık kişiyi bunu azaltmak için bir şeyler yapmaya güdüler. Bu kapsamda başa çıkma terimi, bir kişinin stres yaratan durumlarla uğraşma sürecini anlatmak için kullanılır ${ }^{39}$.

Lazarus ve Folkman ${ }^{40}$ başa çıkmayı, bireyin kaynaklarını aşan veyahut da zorlayan bir şekilde değerlendirilen belirgin içsel ve/veya dışsal istekleri idare etmek için sürekli değişen davranışsal ve bilişsel gayretleri şeklinde tanımlamaktadırlar. Bir diğer değişle başa çıkma, gerçek ile arzu edilip istenilen birbirinden belirgin bir şekilde ayrıldığında, bu durumu idare etme, kontrol altında tutma çabasıdır ${ }^{41}$. Diğer bir tanımdaysa, yerine getirilmesi gereken bir kısım görevleri, aşırı zorlayıcı bir görevin üstesinden gelmek için ertelerken, olabilecek en verimli bir şekilde gayret sarf etmek ve yine hem içsel hem de dışsal streslerle baş etmek üzere gelişen stratejileri içeren, ağır koşullar altındaki bir idare etme süreci olarak ifade edilmektedir ${ }^{42}$. Pargament ve Park ise başa çıkmanın; yaşamı tehdit eden hastalıklar, ani trajediler ve ölümler karşısında tepkisel bir yanıt olabileceği gibi gelecekle alakalı hedefe yönelik bir süreç de

36 D. Z. Phillips, The Concept of Prayer (London: Routledge and Kegan Paul, 1965), 56, akt., Albayrak, Gençlerde Dua Psikolojisi, 39.

37 Carrel, Duâ, 29; Argyle, Psychology and Religion: An Introduction, 95; David M. Wulff, Psychology of Religion Classic and Contemporary (New York: John Wiley \& Sons, 1991), 167-168; Lee A. Kirkpatrick, "Attachmet Theory and Religious Experience", Handbook of Religious Experience, ed. Ralph W. Hood (Birmingham: Religious Education Press, 1995), 457; Marinier, Dua Üzerine Düşünceler (Psikofizyolojik sebepleri ve sonuçları), 37-38; Hayati Hökelekli, İslam Psikolojisi Yazıları (İstanbul: Dem Yayınları, 2009), 72; Gazâlî, Ihyâuu ulûmi'd-dîn, trc. Ahmet Serdaroğlu (İstanbul: Bedir Yayınevi, 1989), 1: 297-302.

38 Kenneth I. Pargament v.dğr., "Patterns of Positive and Negative Religious Coping with Major Life Stressors”, Journal for the Scientific Study of Religion 37/4 (1998): 710-724; J. P. Bjorck - J. W. Thurman, “Negative Life Events, Patterns of Positive and Negative Religious Coping, and Psychological Functioning", Journal for the Scientific Study of Religion 46/2 (2007): 159-167; Akif Hayta, "ibadetler ve Ruh Sağlığı (Dini Pratikler ile Psiko-Sosyal Uyum Arasındaki İlişki Üzerine Bir İnceleme)", Gençlik Din ve Değerler Eğitimi, ed. Hayati Hökelekli (İstanbul: Dem Yayınları, 2006), 137-180; Naci Kula, "Gençlerde Istırap Tecrübesine Bağlı Dini Krizle Başa Çıkmaya Yönelik Öneriler", Gençlik Dönemi ve Eğitimi - II (İstanbul: Ensar Yayınları, 2003), 103-131; Nurten Kimter, “Dini İnanç, İbadet ve Dua'nın Umutsuzlukla İlişkisi Üzerine Bir Araştırma (Üniversite Öğrencileri Üzerine)", Gençlik Din ve Değerler Psikolojisi, ed. Hayati Hökelekli (İstanbul: Dem Yayınları, 2006), 217-250.

39 E. E. Smith v.dğr., Atkinson \& Hilgard Psikolojiye Giriş, trc. Ö. Öncül - D. Ferhatoğlu, 14. Baskı (Ankara: Arkadaş Yayınevi, 2012), 515; Ayten, Tanrı'ya Sığınmak, 37.

40 Lazarus - Folkman, Stres, Appraisal and Coping, 141.

41 Ayten, Tanrı'ya Sı̆̆ınmak, 38.

42 David Matsumoto, The Cambridge Dictionary of Psychology (New York: Cambridge University Press, 2009), 134. 
olabileceğini belirtmişlerdir. Onlar, netice itibarı ile başa çıkmanın, insanların en derinden önemsedikleri şeyleri korumaya, muhafaza edip sürdürmeye veya dönüştürmeye yönelik teşebbüsleri içerdiğini ifade etmişlerdir ${ }^{43}$.

\subsection{Başa Çıkma Tarzları}

Başa çıkma mekanizmaları kaynaklar, tarzlar ve belirli çabalar şeklinde sınıflandırılmaktadır. Başa çıkma kaynakları, bireyin problem çözme becerilerini, kişilerarası ilişkilerde becerilerini, olumlu benlik kavramı gibi kişiliğin bazı yönlerini ve sosyal desteklerini oluştururken; başa çıkma tarzları belli durumlarda genellikle kullandığı ya da benzer durumlarda zaman içinde tekrarladığı başa çıkma yöntemlerini kapsamaktadır. Bunlar aynı zamanda kişinin tercihlerinin, dolaylı olarak da inançlarının ve değerlerinin yansımasıdır. Başa çıkma çabaları ise, belirli bir stres oluşturucu durumda kullanılan bilişsel ya da davranışsal stratejilerdir ve stresli olayın bağlamına göre değişmektedir ${ }^{44}$.

Yapılan deneysel araştırmalar sonucunda, başa çıkma stratejilerinin temel olarak problem odaklı başa çıkma ve duygu odaklı başa çıkma olmak üzere iki kategoride toplandığı görülmüştür ${ }^{45}$. Problem odaklı başa çıkma bireyin, durumu değiştirmek, stresin etkilerini azaltmak veya onu bertaraf etmek için nelerin yapılabileceği üzerinde odaklandığı başa çıkma tarzıdır. Problem odaklı stratejilerde, öncelikle sorunun tanınması gerekir. Daha sonra alternatif çözümler geliştirilebilir. Ardından bu alternatifler çeşitli açılardan (yarar, maliyet vs.) değerlendirilebilir. Son olarak ise alternatif çözümler arasında seçim yapılır ve uygulamaya geçilir ${ }^{46}$. Stres oluşturan durumlarda problem odaklı başa çıkmayı kullanma eğiliminde olan bireyler, stres oluşturan durum sırasında ve sonrasında daha düşük depresyon düzeyleri gösterirler ${ }^{47}$.

İnsanlar olumsuz duyguların egemenliği altına girmeyi ve bu duyguların problem çözme eylemlerini etkilemesini önlemek için bir diğer başa çıkma tarzı olan duygu odaklı başa çıkmayı uygulamaya çalışırlar. Duygusal odaklı başa çıkmada, problem odaklı başa çıkmada olduğu üzere bir değişim arama yerine, stres veren duruma ilişkin yaşanan duygularda ayarlamaya gitmeyi içerir. Bu başa çıkma stratejisi, stres veren durumlara yönelik, bilişsel süreçleri, doğrudan duygusal tercihlere dönüştürerek, tehdit durumunu azaltma, basitleştirme, sorunun sadece bir yönü ile ilgilenme, olumlu karşılaştırmalar yapma, olumsuz

43 Kenneth I. Pargament - Crystal L. Park, "In Times of Stress: The Religion-Coping Connection", The Psychology of Religion: Theoretical Approaches, ed. B. Spilka - D. N. McIntosh (Boulder: Westview Press, 1997), 44; Kenneth I. Pargament v.dğr., "Religion and Coping", Aging, Spirituality, and Religion: A Handbook, ed. M. Kimble v.dğr. (Minneapolis: Fortress Press, 1995), 48.

44 Şahin - Durak, "Stresle Başaçıkma Tarzları Ölçeği", 57.

45 Richard S. Lazarus - Bernice N. Lazarus, Coping with Aging (New York: Oxford University Press, 2006$), 57$.

46 Lazarus - Lazarus, Coping with Aging, 57; Smith v.dğr., Atkinson \& Hilgard Psikolojiye Giriş, 515; Şahin - Durak, "Stresle Başaçıkma Tarzları Ölçeği", 57.

47 Smith v.dğr., Atkinson \& Hilgard Psikolojiye Giriş, 515. 
durumları olumlu olabilecek yönleri ile görmeye çalışma gibi açıklamalar içerir ${ }^{48}$. Duygu odaklı başa çıkma tarzları literatürün bir kısmında Freudyen savunma mekanizmaları ile özdeş tutulmuştur ${ }^{49}$.

\subsection{Dini Başa Çıkma}

Her fert, hayat karşısında kendine özgü bir yönelim sistemine sahiptir. Bu yönelim sistemi, kutsal veya seküler temelli olabilir. Bireylerin karşılaştıkları olayları nasıl yorumlayacağı, başlarına gelenlere ilişkin yapacakları nedensel açıklamalar ve problemleri çözmelerinde nasıl bir tavır takınacakları konusunda bu sistem belirleyici olur ${ }^{50}$. Bu bağlamda Pargament ${ }^{51}$, karşı karşıya kalınan problemlere bir anlam vermede ve onları filtre etmemizde dinin, bilişsel bir şema ve zihinsel bir temsil sunduğunu ifade eder. Brown da dini inançların, karşılaşılan belirsizlikleri aydınlatmada, etrafta olup biten olumlu ya da olumsuz olayları anlamlandırmada, sorunlarla baş etmede, onları yorumlayabilmek ve açıklayabilmek için bireylerin başvurup kullandıkları zihni kategoriler olduğunu söyler ${ }^{52}$.

İnsanlar stres oluşturan bir olay veya durumla karşılaştıklarında, bu stresli durum veya olaydan kurtulmak için inançlarından, dini pratiklerden ve insanlar arası ilişkilerden oluşan bir sistemden yararlanmaktadırlar ${ }^{53}$. Başa çıkma teorisi stres altında olunduğu zamanlarda dinin rolünü anlamak için bir çatı sağlar ${ }^{54}$. Koenig, Pargament ve Nilsen ${ }^{55}$, dini başa çıkmayı, stresli yaşam koşullarının negatif duygusal sonuçlarını önlemek veya azaltmak ve problem çözmeyi kolaylaştırmak için dini inançların veya davranışların kullanımı olarak tanımlamaktadırlar.

\subsubsection{Dini Başa Çıkma Tarzları}

Pargament, postulat olarak kendi kendini yöneten, işbirlikçi ve ertelemeci olmak üzere üç dini başa çıkma tarzının olduğunu ileri sürmüştür. Her bir sitil de aktivite düzeyi ve sorumluluk odağı olmak üzere iki temel boyuttan oluşur. Kendini yönetme tarzı dini başa çıkma, bireyin aktif bir problem çözme tavrı takındığı ve doğrudan Tanrıyı içermeyen aynı zamanda da din karşıtı olmayan bir başa çıkma tarzıdır. Bu tarzda tanrı, insanın kendi yaşamında kendini yönetmesi için imkânlar ve özgürlük veren bir güçtür. Bir diğer dini başa çıkma tarzı olan

48 Smith v.dğr., Atkinson \& Hilgard Psikolojiye Giriş, 515; Lazarus - Lazarus, Coping with Aging, 57; F. Tekin, Stresle Başa Çıkmada Din Eğitiminin Rolü (Doktora Tezi, Selçuk Üniversitesi 2005), 21; F. Genç, Kemoterapi Alan Akciğer Kanserli Hastalarda Görülen Semptomlar ve Başa Çıkma Tarzları (Yüksek Lisans Tezi, Atatürk Üniversitesi, 2005$), 27$.

49 Halil Ekşi, Başaçıkma, Dini Başaçıkma ve Ruh Sağlığı Arasındaki Ilişki Üzerine Bir Araştırma Eğitim, Ilahiyat ve Mühendislik Fakültesi Öğrencilerinin Karşılaştırılması. (Doktora Tezi, Uludağ Üniversitesi, 2001), 23.

50 Ayten, Tanrı'ya Sığınmak, 40.

51 Pargament, The Psychology of Religion and Coping, 193.

52 L. B. Brown, "The Structure of Religious Belief", Journal for the Scientific Study of Religion 5 (1966), akt. Recep Yaparel, “Depresyon ve Dini İnançlar İle Tabiatüstü Nedensel Yüklemeler Arasındaki Ilişkiler", Dokuz Eylül Üniversitesi ilahiyat Fakültesi Dergisi 8 (1994): 279.

53 Topuz, Dini Gelişim Seviyeleri ile Dini Başaçıkma Tutumları Arasındaki Ilişki, 66.

54 Pargament - Park, "In Times of Stress: The Religion-Coping Connection", 43.

55 Harold G. Koening v.dğr., "Religious Coping and Health Status in Medically III Hospitalized Older Adults", The Journal of Nervous \& Mental Disease 186/9 (1998): 513. 
ve dilimize Tanrıya havale edici olarak çevirebileceğimiz ertelemeci tarzda ise birey karşı karşıya kaldığı problemi tanrıya havale eder ve onun tarafından çözülmesini bekler. Son olarak işbirlikçi dini başa çıkma tarzına gelince burada da sorun çözme sürecinde hem Tanrı hem de birey aktif bir şekilde ortaklaşa çözüm sürecinde yer alır ${ }^{56}$.

Ayrıca Pargament, Smith, Koenig ve $\mathrm{Perez}^{57}$ tarafından gerçekleştirilen araştırmalar neticesinde, dindar insanların genel olarak olumlu ve olumsuz olmak üzere iki tür başa çıkma yöntemine başvurduklarını tespit edilmiştir. Onlar pozitif dinî başa çıkma metotlarından oluşan örüntünün, Tanrı ile güvenli bir ilişkiden, bir maneviyat duygusundan, hayatta bir anlam bulunduğu inancından ve başkalarıyla manevî bir bağlanma duygusundan kaynaklandığını iddia etmişlerdir. Pozitif dinî başa çıkma metotları, olumsuz durumları hayra yoran (hayırhah) dinî değerlendirilişleri, işbirlikçi dinî başa çıkmayı, Tanrı'dan manevi destek arayışını, din adamı ya da cemaat üyelerinden destek arayışını, başkalarına dinî yardımı ve dinî affı kapsar. Buna karşııık negatif dinî başa çıkma metotlarından oluşan örüntü ise bir gerilim ve karmaşada Tanrı ile zayıf bir ilişki, yüzeysel ve uğursuz bir dünya görüşüdür. Negatif dinî başa çıkma yöntemleri Tanrı́nın gücünü sorgulamayı, Tanrı'ya karşı kızgınlık ifadelerini, cemaat ve din adamlarına yönelik hoşnutsuzluk ifadelerini, menfi durumların ceza kabilinden dinî değerlendirilişlerini ve bedhah (şerre yoran) dinî değerlendirilişleri kapsar ${ }^{58}$.

\subsubsection{Dini Başa Çıkmanın Bir Unsuru Olarak Dua}

Dua, şükür, affetme, alçakgönüllülük, sabır, itaat, tevekkül ve kabul etme dini başa çıkmanın önde gelen unsurlarındandır ${ }^{59}$. Bu unsurlar içerisinde belki de en belirgin olanı, Allah'a yönelerek O'ndan yardım istemenin somut ifadesi olan duadır. Pek çok psikoloğa göre de dinin özü ve ruhu olan dua, dini başa çıkma sürecinde başvurulan tek dini uygulama olmamakla birlikte, zor durumda kalan insanların sıkıntılarından kurtulmak için öncelikle ve sıklıkla başvurdukları bir dini etkinliktir ${ }^{60}$.

Topuz ${ }^{61}$ duayı, dini başa çıkmanın başladığı "an" olarak nitelendirmektedir. $\mathrm{O}$, insanın hemen duaya başlamasının sebebinin, ilahi bir güçten yardım alma

56 Pargament, The Psychology of Religion and Coping, 180-183; Kenneth I. Pargament, "Acı ve Tatı: Dindarlığın Bedelleri ve Faydaları Üzerine Bir Değerlendirme", trc. Ali Ulvi Mehmedoğlu, Çukurova Üniversitesi Illahiyat Fakültesi Dergisi 5/1 (2005): 286; Pargament - Park, "In Times of Stress: The Religion-Coping Connection", 47.

57 Pargament v.dğr., "Patterns of Positive and Negative Religious Coping with Major Life Stressors".

58 Pargament, "Acı ve Tatı: Dindarlığın Bedelleri ve Faydaları Üzerine Bir Değerlendirme”, 287; C. A. Lewis v.dğr., "Religious Orientation, Religious Coping and Happiness Among UK Adults", Personality and Individual Differences, 38 (2005): 1196

59 Pargament, The Psychology of Religion and Coping, 178.

60 S. Banziger v.dğr., "Praying and Coping: The Relation Between Varieties of Praying and Religious Coping Styles", Mental Health, Religion \& Culture 11/1 (2008): 103; Küçükcan - Köse, Doğal Afetler ve Din, 151; Ayten, Tanrı́ya Sığınmak, 42.

61 Topuz, Dini Gelişim Seviyeleri ile Dini Başaçıkma Tutumları Arasındaki Illişki. 71. 
isteği olduğunu söyler. Yaş, cinsiyet, gelir durumu ve eğitim durumu gibi kişisel unsurlara bağlı olmadan, her türlü problemin çözümünde kullanılan dua, canlı ve anlamlı bir başa çıkma stratejisidir. Yapılan araştırmalar, bilimsel bilgilerin yetersiz olduğu durumlarda, insanların dua aracılığı ile durumu Allah'a bildirdikleri, tıbbi bilginin yetersiz olduğu durumlarda dua eden insanların daha rahat ve sakin oldukları, en fazla kızgınlık anlarında dua edildiğini göstermektedir ${ }^{62}$. Yani belirsizlik arttıkça, tahmin edilebilirlik ve denetlenebilirlik de azaldıkça dua etme sıklığı artmaktadır. Ancak Amerika'da Centralia'daki bir yangın felaketi bu bakış açısıyla incelendiğinde farklı bir durum ortaya çıkmaktadır. Bu yangın felaketinin menşeinin açık olmasına ve dini olmayan sistemlerin problemin çözümünü sağlayabilecek olmasına rağmen bu felakete din tamamen ilgisiz olmamıştır. $\mathrm{Bu}$ durumu idrak eden birçok sakin yine de felaket esnasında dua etmiştir. $\mathrm{Bu}$ durumda şunu ortaya koymaktadır ki onların duaları problemleri çözme fonksiyonundan ziyade aklı koruma, umut ve kontrol etme gibi önemli manevi ve psikolojik amaçlara hizmet etmektedir ${ }^{63}$. Nitekim sıkıntılı, bunalımlı ve gergin bir durumda duanın etkisi yatışma ve rahatlatma şeklinde kendini gösterir ${ }^{64}$.

\section{3. Çalışmanın Yöntemi}

Çalışmada yöntem olarak, dökümantasyon ve nicel araştırmalar kapsamında tanımlanan tarama ve korelasyonel araştırma modeli kullanılmıştır. Veriler ise anket tekniğinden yararlanılarak toplanılmıştır. Araştırmanın amacına ve modeline uygun olarak geliştirilen bağımlı ve bağımsız değişkenler arasındaki muhtemel ilişkiler Şekil 1'de gösterilmektedir.

Şekil 1: Araştırmanın Bağımlı-Bağımsız Değişkenleri ve Aralarındaki îlişkiler.

\begin{tabular}{|l|l|l|l|}
\hline $\begin{array}{l}\text { Demografik } \\
\text { Değişkenler } \\
\text { - Cinsiyet } \\
\text { - Yaş } \\
\text { - Medeni durum } \\
\text { - Sosyal çevre } \\
\text { - Gelir algısı } \\
\text { - Eğitim durumu }\end{array}$ & $\begin{array}{l}\text { Dua Ölçeği } \\
\text { Tefekkür ve rahatlama } \\
\text { İstek ve şükür } \\
\text { Manevi hoşnutsuzluk }\end{array}$ & $\begin{array}{l}\text { Başa Çıkma Tarzları Ölçeği } \\
\text { Kendine güvenli yaklaşım } \\
\text { Çaresiz yaklaşım } \\
\text { Boyun eğici yaklaşım } \\
\text { lyimser yaklaşım } \\
\text { Sosyal destek arama }\end{array}$ \\
Dinsel Eğilim Ölçeği
\end{tabular}

62 Topuz, Dini Gelişim Seviyeleri ile Dini Başaçıkma Tutumları Arasındaki Ilişki, 71.

63 Kenneth I. Pargament, "'Tanrım Bana Yardım Et' Din Psikolojisi Açııından Başa Çıkmanın Teorik Çatısına Doğru”, trc. Ahmet Albayrak Tabula Rasa 9 (2003): 224.

64 Naci Kula, “Deprem ve Dini Başa Çıkma”, Gazi Üniversitesi Çorum Ilahiyat Fakültesi Dergisi 1 (2002): 246; Albayrak, Gençlerde Dua Psikolojisi, 80. 


\section{1. Örneklem ve Olgusal Durum}

Araştırmanınörneklemini, Sakaryailinde ilkyetişkinlik çağında bulunan 415 kişi temsil etmektedir. Araştırma örneklemine giren bireyler basit tesadüfi örnekleme tekniği65 kullanılarak belirlenmiştir. Katılımcıların \% 42,4'ünü ( $n=176)$ erkekler, \%57,6'sını ( $\mathrm{n}=239$ ) kadınlar oluşturmaktadır. Katılımcıların yaşları 20 ile 45 arasında değişmektedir. Araştırma gurubunun yaş ortalaması ise 30,52'dir. Katılımcıların yaşları ilk yetişkinlik gelişim dönemlerine uygun olarak kategorileştirilmiştir ${ }^{66}$. Buna göre örneklem gurubunun \%11,6'sı (48 kişi) ilk yetişkinliğe geçiş, \% 37,8'i (157 kişi) ilk yetişkinlik için yaşam yapısı girişi, \%19,3'ü (80 kişi) otuz yaş geçişi, \% 21,0 'i (87 kişi) ilk yetişkinliğin yaşam yapısını sonuçlandırma, ve son olarak ise \% 10,4'ü (43 kişi) ilk yetişkinliğin bitişi orta yetişkinliğin başlangıcı olan orta yaş geçişi dönemindeki bireylerden oluşmaktadır. Katılımcıların \% 50,4'ü (209) bekârlar, \% 49,6'sı (206) ise evlilerden oluşmaktadır. Örneklemi teşkil eden katılımcıların büyük çoğunluğu (\%66,7'si 277 kişi), hayatının çoğunu şehirlerde geçirdiğini belirtmiştir. Daha sonra da sırasıyla hayatının çoğunluğunu ilçe (\%21,2'si 88 kişi), köy (\%9,6'sı 40 kişi) ve kasabada (\%2,4'ü 10 kişi) geçirenler gelmektedir. Ancak araştırmada köyle kasaba değişkeni, hem denek sayısının az olmasından hem de benzer özellikleri taşıyan çevreler olmasından dolayı recode yapılarak birleştirilmiş ve bu şekilde analize dâhil edilmiştir. Araştırma örnekleminin gelir algısına göre dağılımı ise şu şekildedir. Katılımcıların \% 48,9'i ( $n=199)$ gelir algısını iyi, \% 44,6'sı ( $n=185)$ orta, \% 4,8'i ( $n=20)$ düşük ve \% 2,7'si $(n=11)$ çok iyi olarak belirtmiştir. Ancak araştırmada, çok iyi ile iyi değişkeniyle orta ve düşük değişkenleri, hem örneklem sayısının az olmasından ötürü hem de birbirine yakın gruplar olmasından dolayı birleştirilmiştir. Örneklemi oluşturan katılımcıların, $\% 64,1$ 'ini ( $n=266)$ üniversite mezunları, \%24,3'ünü ( $n=101)$ lisansüstü mezunları, $\% 7,7^{\prime}$ sini $(n=32)$ lise mezunları, \% 2,2'sini ( $\left.n=9\right)$ ortaokul mezunları ve \% 1,7'sini $(\mathrm{n}=7)$ ise ilkokul mezunları oluşturmaktadır. Ancak çalışmada ilkokul, ortaokul ve lise değişkenleri örneklem sayısının az olmasından ötürü birleştirilmiştir.

\section{2. Ölçme Araçları}

Araştırmada bilgi toplama ve ölçme amacıyla anket tekniğine başvurulmuştur. Anket formunda kişisel bilgi formu, dua ölçeği, dinsel eğilim ölçeği ve başa çıkma tarzları ölçeği kullanılmıştır.

65 Bkz., Remzi Altunışık v.dğr., Sosyal Bilimlerde Araştırma Yöntemleri SPSS Uygulamalı, 7. Baskı (Sakarya: Sakarya Yayıncılık, 2012), 139.

66 Bekir Onur, Gelişim Psikolojisi Yetişkinlik-Yaşılık-Ölüm (Ankara: İmge Kitabevi, 2011), 82; Ali Eryılmaz, “Bir Yaşam Dönemi Olarak Yetişkinlik: Tanımı, Ölçütleri ve Kuramları", Yetişkinlik ve Yaşılıı Gelişimi ve Psikolojisi, ed. Hasan Bacanlı - Şerife Terzi (İstanbul: Açılım Kitap, 2012), 67. 


\subsubsection{Dua Ölçeği}

Araştırmada katılımcıların dua tutumlarını ölçmek için Yaman ve Temiz ${ }^{67}$ tarafından geliştirilen Dua Ölçeği kullanılmıştır. Dua ölçeği 23 madde ve 3 alt boyuttan oluşmaktadır. Ölçeğin alt boyutları tefekkür ve rahatlama, istek ve şükürle manevi hoşnutsuzluk boyutlarıdır. Manevi hoşnutsuzluk boyutundaki maddeler ters puanlanmıştır. Maddelerin derecelendirilmesinde, çift sayıda kategori içeren 4'lü Likert tipi bir derecelendirme kullanılmıştır. Ölçekten alınan puanların yükselmesi olumlu dua tutumuna sahip olmayı gösterirken, puanların düşmesi ise olumsuz bir dua tutumunu ortaya koymaktadır.

Ölçeğin yapı geçerliğini test etmek üzere yapılan faktör analizi neticesinde, Kaiser-Mayer-Olkin (KMO) örneklem uygunluk katsayısının ,944; Barlett Sphericity Testi $x^{2}$ değerinin 4463.799 ( $p<.001$ ) olduğu tespit edilmiştir. Ölçeğin üç boyuttan oluştuğu ve varyansı açıklayıcılık oranının \% 54.21 olduğu hesaplanmıştır. Ölçeğin güvenirliğini test etmek amacıyla yapılan iç tutarlık analizi neticesinde ise, Cronbach Alpha değeri .917 olarak hesaplanmıştır.

\subsubsection{Stresle Başa Çıkma Tarzları Ölçeği}

Folkman ve Lazarus'un "Başaçıkma Yolları Envanteri", 66 maddelik 4'lü likert tipi bir ölçektir. Bu ölçek ülkemizde öncelikle Siva (1988) tarafından kullanılmış ve kültüre özgü maddeler eklenerek 74 maddelik bir ölçek haline getirilmiştir. 74 maddelik "Başaçıkma Yolları Envanteri"nin Şahin ve Durak tarafından yapılan kısaltma çalışması sonunda ölçek 30 maddeye indirilmiştır. Kısaltılmış ölçek kendine güvenli yaklaşım, çaresiz yaklaşım, boyun eğici yaklaşım, iyimser yaklaşım ve sosyal desteğe başvurma olmak üzere 5 faktörden oluşmaktadır. Sosyal desteğe başvurma boyutundaki 1. ve 9. maddeler ters maddelerdir. Ölçek kapsamlı bir çözümlemeye tabi tutulduğunda ölçeğin 5 alt boyutu, Problem odaklı/aktif başa çıkma tarzları (kendine güvenli yaklaşım, iyimser yaklaşım, sosyal destek arama) ve Duygusal odaklı/pasif başa çıkma tarzları (çaresiz yaklaşım, boyun eğici yaklaşım) olmak üzere 2 üst faktörde toplanmaktadır ${ }^{68}$.

Ölçeğin yapı geçerliğini test etmek üzere yapılan faktör analizi neticesinde, Kaiser-Mayer-Olkin (KMO) değerinin ,800; Barlett Sphericity Testi $X^{2}$ değerinin $2952.153(p<.001)$ olduğu bulunmuştur. Ölçeğin 5 boyuttan oluştuğu ve 5 boyutun birlikte açıkladığı varyans oranının \% 43,47 olduğu gözlemlenmiştir. Ölçeğin güvenirliğini test etmek amacıyla yapılan iç tutarlık analizi neticesinde ise Cronbach Alpha değeri .602 olarak hesaplanmıştır. Alfa değeri .70'in altında olmakla birlikte kabul edilebilir düzeydedir. Şahin ve Durak tarafından yapılan çalışmada ölçeğin 5 faktörlü çözümlemesinde açıklanan toplam varyansın

67 Erkan Yaman - Yunus E. Temiz, “Dua Ölçeği'nin Geliştirilmesi: Geçerlik ve Güvenirlik Çalışması”, Değerler Eğitimi Dergisi 12/28 (2014): 193-219.

68 Şahin - Durak, "Stresle Başaçıkma Tarzları Ölçeği", 56-73. 
\%40.4 olduğu rapor edilmiştir ${ }^{69}$. Büyüköztürk tek faktörlü ölçeklerde açıklanan varyansın \%30 ve daha fazla olmasının yeterli görülebileceğini söylerken, çok faktörlü ölçeklerde ise açıklanan varyansın daha fazla olmasının beklendiğini belirtmiştir $^{70}$. Ölçüm aracı bu haliyle kabul edilebilir olmakla birlikte gözden geçirilerek geliş̧tirilmelidir.

\subsubsection{Dinsel Eğilim Ölçeği}

Araştırmada katılımcıların dinsel eğilim düzeylerini ölçmek için Gordon W. Allport ve Ross tarafından geliştirilen ve Hasan Kayıklık tarafından Türkçe'ye uyarlaması yapılan Dinsel Eğilim Ölçeği kullanılmıştır. Kayıklık tarafından yapılan Türkçe'ye uyarlama çalışmaları sonucunda ölçek, 10 maddeli, tek faktörlü bir ölçme aracı haline gelmiştir. 4., 5., 7. ve 10. maddeler ters maddelerdir. Maddelerin derecelendirilmesinde, çift sayıda kategori içeren 4'lü Likert tipi bir derecelendirme kullanılmıştır. Ölçekten alınan puanların yükselmesi iç güdümlü dindarlığın arttığını gösterirken, puanların düşmesi de dış güdümlü dindarlığın arttığını göstermektedir ${ }^{71}$.

Ölçeğin yapı geçerliğini test etmek üzere yapılan faktör analizi neticesinde, Kaiser-Mayer-Olkin (KMO) örneklem uygunluk katsayısının ,854; Bartlett's Test of Sphericity değerinin $\left(X^{2}=979,530 ; p<.001\right)$ olduğu tespit edilmiştir. Ölçeğin tek boyuttan oluştuğu ve varyansı açıklayıcılık oranının \% 36,49 olduğu gözlemlenmiştir. Ölçeğin güvenirliğini test etmek amacıyla yapılan iç tutarlık analizi neticesinde ise, Cronbach Alpha değeri .79 olarak hesaplanmıştır. Dinsel Eğilim Ölçeği tek faktörlü bir ölçme aracı olduğundan açıklanan varyansın \%36,49 olması kabul edilebilir. Kayıklık tarafından yapılan çalışmada da tek faktörün açıkladığı varyans miktarının \%36 olduğu bildirilmiştir ${ }^{72}$. Ölçüm aracı bu haliyle kabul edilebilir düzeyde olmakla birlikte gözden geçirilerek geliştirilebilir.

\subsection{Verilerin Analizi}

Araştırmada bilgi toplama ve ölçme araçlarıyla elde edilen bilgilerin bilgisayar ortamına aktarılması ve analizleri SPSS 20 paket program yardımıyla yapılmıştır. Aktarılan veriler üzerinde yapılan veri temizleme işleminden sonra, anketi oluşturan bazı maddelere atanan sayısal değerler yeniden kodlama yoluyla değiştirilmiştir. Bazı değiş̧enler (yaş, sosyal çevre, gelir algısı, eğitim durumu, sağlık algısı) yeniden tanımlanmış ve veri dönüştürme işlemleri uygulanmıştır. Gerçekleştirilen ön analizler neticesinde verilerin normal dağılım gösterdiği araştırmada parametrik testler kullanılmıştır.

69 Şahin - Durak, "Stresle Başaçıkma Tarzları Ölçeği", 60.

70 Şener Büyüköztürk, Sosyal Bilimler için Veri Analizi El Kitabı (Ankara, Pegem Akademi, 2012), 125.

71 Hasan Kayıklık, Dini Yaşayış Biçimleri: Psikolojik Temelleri Açısından Bir Değerlendirme (Doktora Tezi, Dokuz Eylül Üniversitesi, 2000), 61-64.

72 Kayıklık, Dini Yaşayış Biçimleri, 63. 


\section{Bulgular ve Yorumlar}

\subsection{Cinsiyet Değişkeni Açısından Dua}

Araştırmanın bu kısmında "cinsiyet değişkeni bireylerin dua tutumlarında herhangi bir farklılığa yol açmakta mıdır?" sorusuna cevap aranmaktadır. Bunu tespit etmek amacıyla gruplar arası t testi uygulanmış ve sonuçlar Tablo 1'de sunulmuştur.

Tablo 1: Dua tutumu bakımından kadınlarla erkekler arasındaki farklar (t test)

\begin{tabular}{|c|c|c|c|c|c|c|c|}
\hline & Cinsiyet & $\mathbf{N}$ & $\mathbf{x}$ & $\mathbf{S}$ & sd & $\mathbf{t}$ & $\mathbf{p}$ \\
\hline \multirow{2}{*}{$\begin{array}{l}\text { Tefekkür ve } \\
\text { rahatlama }\end{array}$} & Erkek & 176 & 27,07 & 4,44 & \multirow{2}{*}{305} & \multirow{2}{*}{1,691} & \multirow{2}{*}{ 092 } \\
\hline & Kadın & 239 & 27,74 & 3,25 & & & \\
\hline \multirow{2}{*}{ İstek ve Şükür } & Erkek & 176 & 30,97 & 4,56 & \multirow{2}{*}{413} & \multirow{2}{*}{1,246} & \multirow{2}{*}{ 214 } \\
\hline & Kadın & 239 & 31,46 & 3,49 & & & \\
\hline \multirow{2}{*}{$\begin{array}{l}\text { Manevi } \\
\text { Hoşnutsuzluk }\end{array}$} & Erkek & 176 & 21,68 & 2,24 & \multirow{2}{*}{411} & \multirow{2}{*}{3,350} & \multirow{2}{*}{,001 } \\
\hline & Kadın & 239 & 20,84 & 2,85 & & & \\
\hline \multirow{2}{*}{ Dua (Genel) } & Erkek & 176 & 79,73 & 9,57 & \multirow{2}{*}{413} & \multirow{2}{*}{376} & \multirow{2}{*}{ 707 } \\
\hline & Kadın & 239 & 80,06 & 7,97 & & & \\
\hline
\end{tabular}

Tablo 1'de görüldüğü üzere, dua ölçeği genelinde erkekler $(x=79,73)$ ve kadınlar $(x=80,06)$ arasında anlamlı bir farklılık gözlenmemektedir, t $(413)=376$, $p>.05$. Yalnızca duanın manevi hoşnutsuzluk boyutunda, erkekler $(x=21,68)$ ve kadınlar $(x=20,84)$ arasında erkekler lehine anlamlı bir farklılık gözlenmektedir, $\mathrm{t}(411)=3,350, \mathrm{p}<.01$. Diğer boyutlarda ise gruplar arasında herhangi bir anlamlı farklılık tespit edilmemiştir.

Tablo 1'e genel olarak baktığımızda manevi hoşnutsuzluk boyutu hariç kadınların dua ölçeği ve alt boyutlarından almış oldukları ortalamalar erkeklere göre daha yüksek olmasına rağmen istatistiksel olarak yalnızca bir boyutta anlamlı farklılık gözlenmektedir. Manevi hoşnutsuzluk boyutunda erkekler lehine ortaya çıkan durum, kadınların duygusal olarak sonuca yönelik daha hızlı etkilenmelerini ortaya koymaktadır ${ }^{73}$. Ancak istatistiksel açıdan manevi hoşnutsuzluk boyutu dışında anlamlı farklılığın olmaması ise, kadın ve erkeklerin, duaya dair temel inanç ve esaslar çerçevesinde ortak değerleri benimseme eğiliminde olduklarını düşündürmektedir. 
Cinsiyet-dua ilişkisine dair elde edilen bu bulgular, daha önceki bazı araştırmalarda ulaşılan bulgularla paralellik göstermektedir. Örneğin Albayrak ${ }^{74}$ tarafından üniversite öğrencileri üzerinde gerçekleştirilen bir araştırmada, kız öğrencilerin duaya yönelik tutumları erkek öğrencilere göre daha yüksek bulunmuştur. Arıcı'nın ${ }^{75}$ ergenler üzerine yapmış olduğu araştırmada kızların dua

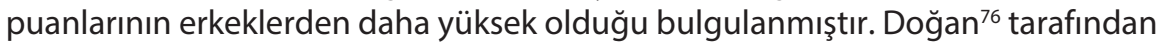
gerçekleştirmiş olan bir diğer çalışmada ise kadınların erkeklerden duanın etkisine daha fazla inandıkları ortaya konmuştur. Sonuç olarak elde edilen veriler ışığında kadınların dua etme eğilimleri, duaya olan inançları erkeklerinkinden daha fazla olduğu tespit edilmiştir ${ }^{77}$.

\subsection{Yaş Değişkeni Açısından Dua}

Araştırmada "bireylerin dua tutumları yaş gruplarına göre farklılık göstermekte midir?" sorusuna cevap aranmaktadır. Bu amaçla yaş değişkeni ilk yetişkinliğin kendi içeresindeki gelişim dönemlerine uygun olarak kategorilendirilmiş ve tek yönlü varyans analizi (ANOVA) yapılmış, gruplar arasındaki farklılığı tespit etmek amacıyla da Scheffe testi uygulanmıştır. Araştırma gurubunun yaş dönemlerine göre dua ölçeği ve alt boyutları puanlarının tanımlayıcı istatistiklerle ANOVA ve Scheffe testi sonuçları Tablo 2'de verilmiştir.

74 Albayrak, Gençlerde Dua Psikolojisi, 111.

75 Asude Arıcı, Ergenlerde Dini Başa Çıkma Yöntemi Olarak Dua (Yüksek Lisans Tezi, Uludağ Üniversitesi, 2005), 112.

76 Mustafa Doğan, Duanın Psikolojik ve Psikoterapik Etkileri (Yüksek Lisans Tezi, Uludağ Üniversitesi, 1997), 55.

77 Bkz, Feim Gashi, Dua ve Hayat Memnuniyeti Üzerine Karşılaştırmalı Bir Araştırma Kırklareli üniversitesi Illahiyat Fakültesi ve Fen-Edebiyat Fakültesi Öğrencileri Örneği Uludağ Üniversitesi Illahiyat Fakültesi Dergisi 25/2 (2016): 12-13. 
Tablo 2: Yaş Dönemlerine Göre Dua Ölçeği Puanlarının Betimsel İstatistiklerle ANOVA ve Scheffe Testi Sonuçları

\begin{tabular}{|c|c|c|c|c|c|c|c|}
\hline & $\begin{array}{c}\text { Yaş } \\
\text { Dönemleri }\end{array}$ & $\mathbf{N}$ & $\mathbf{x}$ & SS & $\mathbf{F}$ & $\mathbf{p}$ & Fark \\
\hline \multirow{5}{*}{$\begin{array}{l}\text { Tefekkür ve } \\
\text { rahatlama }\end{array}$} & 20-23 yaş & 48,00 & 27,29 & 3,44 & & & \\
\hline & 24-28 yaş & 157,00 & 27,50 & 3,87 & & & \\
\hline & 29-33 yaş & 80,00 & 27,15 & 4,32 & 1,486 & 206 & - \\
\hline & $34-40$ yaş & 87,00 & 28,20 & 3,25 & & & \\
\hline & 41-45 yaş & 43,00 & 26,63 & 3,99 & & & \\
\hline \multirow{5}{*}{ İstek ve Şükür } & 20-23 yaş & 48,00 & 31,23 & 3,55 & & & \\
\hline & $24-28$ yaş & 157,00 & 31,44 & 4,04 & & & \\
\hline & 29-33 yaş & 80,00 & 30,80 & 4,71 & ,983 & 417 & - \\
\hline & $34-40$ yaş & 87,00 & 31,71 & 3,35 & & & \\
\hline & 41-45 yaş & 43,00 & 30,53 & 3,95 & & & \\
\hline \multirow{5}{*}{$\begin{array}{l}\text { Manevi } \\
\text { Hoşnutsuzluk }\end{array}$} & 20-23 yaş & 48,00 & 21,63 & 2,16 & & & \\
\hline & 24-28 yaş & 157,00 & 21,14 & 2,65 & & & \\
\hline & 29-33 yaş & 80,00 & 21,09 & 3,01 & 1,621 & , 168 & - \\
\hline & 34-40 yaş & 87,00 & 21,56 & 2,41 & & & \\
\hline & 41-45 yaş & 43,00 & 20,47 & 2,71 & & & \\
\hline \multirow{5}{*}{ Dua (Genel) } & 20-23 yaş & 48,00 & 80,15 & 7,50 & & & \\
\hline & $24-28$ yaş & 157,00 & 80,08 & 8,67 & & & \\
\hline & 29-33 yaş & 80,00 & 79,04 & 9,55 & 1,685 & 153 & - \\
\hline & $34-40$ yaş & 87,00 & 81,47 & 7,86 & & & \\
\hline & 41-45 yaş & 43,00 & 77,63 & 9,47 & & & \\
\hline
\end{tabular}

Tablo 2'te sunulan analiz sonuçları, deneklerin dua ölçeği (genel) puanları arasında yaş dönemleri bakımından anlamlı bir fark olmadığını göstermektedir, $F(4,410)=1,685, p>.05$. Diğer bir ifadeyle, deneklerin dua (genel) puanları, yaş gruplarına göre anlamlı bir şekilde değişmemektedir. Dua-yaş dönemleri ilişkisi, dua ölçeğinin alt boyutları olan tefekkür ve rahatlama, istek ve şükür ile manevi hoşnutsuzluk açısından değerlendirildiğinde ise gruplar arasında istatistiksel olarak anlamlı bir farklılık olmadığı görülmektedir. Bu araştırmada yaş grupları arasındaki aralığın çok fazla olmamasından ötürü yaşa bağlı olarak anlamlı bir farklılaşmanın meydana gelmediğini ifade etmek mümkün gözükmektedir. 
Elde edilen sonuçlar daha önceki bazı araştırmalarda ulaşılan sonuçlarla karşılaştırıldığında bazı araştırmalarla paralellik göstermekteyken ${ }^{78}$ bazı araştırmalarla $^{79}$ örtüşmemektedir. Yapare ${ }^{80}$ tarafından ilk yetişkinler üzerinde yapılan bir araştırmada, farklı yaş gruplarının, dini hayatın boyutlarından olan dua boyutuna ilişkin ortalamaları arasında anlamlı farklılıklar tespit edilmiştir. Albayrak ${ }^{81}$ tarafından üniversite öğrencileri üzerinde yapılan diğer bir araştırmada ise yaş değişkenine göre gruplar arasında dua tutum ve davranışı bakımından anlamlı bir farklılığa rastlanmamıştır.

\subsection{Medeni Durum Açısından Dua}

Çalışmanın bu kısmında "medeni durum değişkeni bireylerin dualarında herhangi bir farklılığa yol açmakta mıdır?" sorusuna cevap aranmış ve bunları tespit etmek amacıyla gruplar arası t testi uygulanmış ve sonuçlar Tablo 3'te sunulmuştur.

Tablo 3: Dua Tutumu Bakımından Bekârlarla Evliler Arasındaki Farklar(t test)

\begin{tabular}{|c|c|c|c|c|c|c|c|}
\hline & Medeni hal & $\mathbf{N}$ & $\mathbf{x}$ & $\mathbf{S}$ & sd & $\mathbf{t}$ & $\mathbf{p}$ \\
\hline \multirow{2}{*}{$\begin{array}{l}\text { Tefekkür ve } \\
\text { rahatlama }\end{array}$} & Bekâr & 209 & 27,33 & 3,87 & \multirow{2}{*}{413} & \multirow{2}{*}{ 674 } & \multirow{2}{*}{,501 } \\
\hline & Evli & 206 & 27,59 & 3,76 & & & \\
\hline \multirow{2}{*}{ İstek ve Şükür } & Bekâr & 209 & 31,08 & 4,15 & \multirow{2}{*}{413} & \multirow{2}{*}{871} & \multirow{2}{*}{,384 } \\
\hline & Evli & 206 & 31,42 & 3,80 & & & \\
\hline \multirow{2}{*}{$\begin{array}{l}\text { Manevi } \\
\text { Hoşnutsuzluk }\end{array}$} & Bekâr & 209 & 21,11 & 2,63 & \multirow{2}{*}{413} & \multirow{2}{*}{ 699 } & \multirow{2}{*}{,485 } \\
\hline & Evli & 206 & 21,29 & 2,64 & & & \\
\hline \multirow{2}{*}{ Dua (Genel) } & Bekâr & 209 & 79,54 & 8,76 & \multirow{2}{*}{413} & \multirow{2}{*}{ 909 } & \multirow{2}{*}{,364 } \\
\hline & Evli & 206 & 80,31 & 8,58 & & & \\
\hline
\end{tabular}

Tablo 3'te sunulan ortalama puanlara göre, dua ölçeği geneli için, bekârlar $(x=79,54)$ ve evliler $(x=80,31)$ arasında anlamlı bir farklılık gözlenmemektedir, $\mathrm{t}(413)=, 909, \quad p>.05$. Dua ölçeği alt boyutlarında da medeni durum bakımından istatistiki açıdan bekârlar ve evliler arasında anlamlı bir farklıı̆ga rastlanılmamaktadır.

Ancak Tablo 3 incelendiğinde, gruplar arasında anlamlı bir farklılık tespit edilememekle birlikte dua ölçeği ve alt boyutlarında, evlilerin ortalama puanları bekârlara göre daha yüksek gözlenmektedir. Gruplar arasındaki farklıı̆ın

78 Albayrak, Gençlerde Dua Psikolojisi, 108.

79 Recep Yaparel, Yirmi-Kırk Yaşlar Arası kişilerde Dini Hayat Ile Psiko-Sosyal Uyum Arasındaki Ilişsi Üzerine Bir Araştırma (Doktora Tezi, Ankara Üniversitesi, 1987), 103.

80 Yaparel, Yirmi-Kırk Yaşlar Arası kişilerde Dini Hayat Ille Psiko-Sosyal Uyum Arasındaki Illişki Üzerine Bir Araştırma, 103. 81 Albayrak, Gençlerde Dua Psikolojisi, 108. 
istatistiksel olarak anlamlı seviyeye ulaşamaması, duaya dair temel inanç ve esaslar çerçevesinde grupların ortak değerleri benimseme eğiliminde olduklarını düşündürtmektedir. Yani duanın, dinin en sık başvurulan ibadetlerinden biri olması, ona olan inanç etrafında birleşilmiş olabileceğini akla getirmektedir.

\subsection{Dua ve Sosyal Çevre}

Bu başlık altında, "bireylerin dua tutumları sosyal çevreye göre farklılık göstermekte midir?" sorusuna cevap aranmaktadır. Bu amaçla tek yönlü varyans analizi yapılmıştır. Araştırma grubunun sosyal çevreye göre dua ölçeği ve alt boyutları puanlarının betimsel istatistiklerle ANOVA ve LSD testi sonuçları Tablo 4'te verilmiştir.

Tablo 4: Sosyal Çevreye Göre Dua Ölçeği Puanlarının Betimsel İstatistiklerle ANOVA ve Scheffe Testi Sonuçları

\begin{tabular}{|c|c|c|c|c|c|c|c|}
\hline & Sosyal Çevre & $\mathbf{N}$ & $\mathbf{x}$ & SS & $\mathbf{F}$ & $\mathbf{p}$ & Fark \\
\hline \multirow{3}{*}{$\begin{array}{l}\text { Tefekkür ve } \\
\text { rahatlama }\end{array}$} & Köy-Kasaba & 50 & 27,42 & 4,59 & ,004 & 996 & - \\
\hline & İlçe & 88 & 27,48 & 3,40 & & & \\
\hline & î & 277 & 27,47 & 3,80 & & & \\
\hline \multirow[t]{3}{*}{ İstek ve Şükür } & Köy-Kasaba & 50 & 30,82 & 4,64 & 689 &, 503 & - \\
\hline & İlçe & 88 & 31,63 & 3,21 & & & \\
\hline & il & 277 & 31,22 & 4,08 & & & \\
\hline \multirow{3}{*}{$\begin{array}{l}\text { Manevi } \\
\text { Hoşnutsuzluk }\end{array}$} & Köy-Kasaba & 50 & 21,88 & 2,60 & 2,225 & 109 & - \\
\hline & İlçe & 88 & 21,32 & 2,81 & & & \\
\hline & ìl & 277 & 21,05 & 2,58 & & & \\
\hline \multirow[t]{3}{*}{ Dua (Genel) } & Köy-Kasaba & 50 & 80,12 & 9,64 &, 004 & ,996 & - \\
\hline & ìlçe & 88 & 80,42 & 7,99 & & & \\
\hline & ill & 277 & 79,73 & 8,73 & & & \\
\hline
\end{tabular}

Tablo 4'te sunulan puanlara göre, dua ölçeğinde (genel) en yüksek ortalamaya öncelikle hayatının çoğunu ilçede $(x=80,42)$ geçirenler, daha sonra sırasıyla köykasaba $(x=80,12$ ve il'de $(x=79,73)$ geçirenler sahiptir. Bu farklılığa karşın Tablo 6 incelendiğinde dua düzeyleri bakımından sosyal çevre grupları arasında istatistiksel açıdan anlamlı bir farklılık görülmemektedir, $F(2,412)=, 223, p>, 05$. Dua-sosyal çevre ilişkisi, dua ölçeğinin alt boyutları olan tefekkür ve rahatlama, istek ve şükürle manevi hoşnutsuzluk açısından değerlendirildiğinde ise gruplar arasında yine istatistiksel açıdan anlamlı bir farklılık olmadığı görülmektedir. Ancak Tablo 4 incelendiğinde yaşamının çoğunu kırsal kesimde geçirenlerin ortalamalarının, yaşamının çoğunu kentlerde geçirenlere göre daha yüksek olduğu gözlenmektedir. 
Elde edilen veriler daha önceki bazı araştırmalarda ulaşılan bulgularla paralellik göstermektedir. Albayrak ${ }^{82}$ tarafından üniversite öğrencileri üzerinde gerçekleştirilen araştırmada, sosyal çevre ve dua ilişkisinin istatistiksel açıdan gruplar arasında anlamlı bir farklılık ortaya çıkarmadığı gözlenmiştir. Ancak gerçekleştirilen bu araştırmada da yaşamının çoğunu kırsal kesimde geçirenlerin ortalamaları, yaşamının çoğunu kentlerde geçirenlere göre daha yüksek olduğu ortaya konmuştur. Sonuç olarak grup ortalamaları arasında fark olsa da bu farkın istatistiksel olarak anlamlı seviyede olmaması, kitle iletişim araçlarının köy ve kent yaşamı arasındaki farkı ortadan kaldırmış olabileceğini düşündürtmektedir.

\subsection{Dua ve Gelir Algısı}

Bu başlık altında, "gelir algısı bireylerin dualarında, herhangi bir farklılığa yol açmakta mıdır?" sorusuna yanıt aranmış ve bunları tespit etmek amacıyla gruplar arası t testi gerçekleştirilmiş ve sonuçlar Tablo 5'de gösterilmiştir.

Tablo 5: Dua Tutumu Bakımından Gelir Grupları Arasındaki Farklar (t test)

\begin{tabular}{|c|c|c|c|c|c|c|c|}
\hline & Gelir Algısı & $\mathbf{N}$ & $\mathbf{x}$ & $\mathbf{S}$ & sd & $t$ & $\mathbf{p}$ \\
\hline \multirow{2}{*}{$\begin{array}{l}\text { Tefekkür ve } \\
\text { rahatlama }\end{array}$} & Çok iyi - iyi & 210 & 27,93 & 3,65 & \multirow{2}{*}{413} & \multirow{2}{*}{2,520} & \multirow{2}{*}{,012 } \\
\hline & Orta - Düşük & 205 & 26,99 & 3,93 & & & \\
\hline \multirow{2}{*}{ İstek ve Şükür } & Çok iyi - iyi & 210 & 31,60 & 4,00 & \multirow{2}{*}{413} & \multirow{2}{*}{1,788} & \multirow{2}{*}{,075 } \\
\hline & Orta - Düşük & 205 & 30,90 & 3,95 & & & \\
\hline \multirow{2}{*}{$\begin{array}{l}\text { Manevi } \\
\text { Hoşnutsuzluk }\end{array}$} & Çok iyi - iyi & 210 & 21,41 & 2,64 & \multirow{2}{*}{413} & \multirow{2}{*}{1,639} & \multirow{2}{*}{, 102 } \\
\hline & Orta - Düşük & 205 & 20,99 & 2,63 & & & \\
\hline \multirow{2}{*}{ Dua (Genel) } & Çok iyi - iyi & 210 & 80,94 & 8,36 & \multirow{2}{*}{413} & \multirow{2}{*}{2,432} & \multirow{2}{*}{015} \\
\hline & Orta - Düşük & 205 & 78,88 & 8,89 & & & \\
\hline
\end{tabular}

Tabloda 5'teki ortalama puanlar dikkate alındığında, genel dua ölçeğinden alınan puanlar gelir durumuna göre anlamlı bir farklılık göstermektedir, $t(413)=2,432, p<, 05$. Buna göre gelir durumu çok iyi ve iyi olan deneklerin genel dua ölçeğinden aldıkları puanlar $(x=80,94)$, gelir durumu orta ve düşük olan deneklerin dua ölçeğinden aldıkları puanlara $(x=78,88)$ göre daha yüksektir. Duanın istek ve şükür ile manevi hoşnutsuzluk alt boyutlarında gruplar arasında herhangi bir anlamlı farklılık gözlenmemekle beraber, duanın tefekkür ve rahatlama alt boyutunda her iki grup arasında yine gelir durumu çok iyi ve iyi olanlar lehine anlamlı bir farklılık söz konusudur $\mathrm{t}(413)=2,520, \mathrm{p}<, 05$. Bu bulgular yüksek gelir algısına sahip olanların dua davranışını daha fazla içselleştirdiklerini akla getirmektedir.

82 Albayrak, Gençlerde Dua Psikolojisi, 113. 


\subsection{Dua ve Eğitim Durumu}

Araştırmanın bu kısmında "bireylerin dua tutumları, eğitim durumuna göre farklılık göstermekte midir?" sorusuna cevap aranmaktadır. Bu amaçla ANOVA ve LSD testi uygulanmıştır. Katılımcıların eğitim durumuna göre dua ölçeği ve alt boyutları puanlarının tanımlayıcı istatistikleri ile ANOVA ve LSD testi sonuçları Tablo 6'da verilmiştir.

Tablo 6: Eğitim Durumuna Göre Dua Ölçeği Puanlarının Betimsel İstatistikleri ile ANOVA ve LSD Testi Sonuçları

\begin{tabular}{|c|c|c|c|c|c|c|c|}
\hline & Eğitim D. & $\mathbf{N}$ & $\mathbf{x}$ & SS & $\mathbf{F}$ & $\mathbf{p}$ & Fark \\
\hline \multirow{3}{*}{$\begin{array}{l}\text { Tefekkür ve } \\
\text { Rahatlama }\end{array}$} & İlköğretim-Lise & 48 & 27,21 & 3,95 & 1,897 & 151 & - \\
\hline & Üniversite & 266 & 27,73 & 3,55 & & & \\
\hline & Lisansüstü & 101 & 26,89 & 4,36 & & & \\
\hline \multirow{3}{*}{ İstek ve Şükür } & İlköğretim-Lise & 48 & 31,10 & 3,60 & 2,944 & ,049 & $2-3$ \\
\hline & Üniversite & 266 & 31,86 & 3,53 & & & \\
\hline & Lisansüstü & 101 & 30,01 & 5,07 & & & \\
\hline \multirow{3}{*}{$\begin{array}{l}\text { Manevi } \\
\text { Hoşnutsuzluk }\end{array}$} & İlköğretim-Lise & 48 & 21,44 & 2,62 & 853 & 427 & - \\
\hline & Üniversite & 266 & 21,27 & 2,58 & & & \\
\hline & Lisansüstü & 101 & 20,92 & 2,82 & & & \\
\hline \multirow{3}{*}{ Dua (Genel) } & İlköğretim-Lise & 48 & 79,94 & 8,63 & 2,620 & ,074 & - \\
\hline & Üniversite & 266 & 80,56 & 7,99 & & & \\
\hline & Lisansüstü & 101 & 78,25 & 10,18 & & & \\
\hline
\end{tabular}

Tablo 6'da sunulan analiz sonuçları, deneklerin dua ölçeği (genel) puanları arasında eğitim durumları bakımından anlamlı bir fark olmadığını göstermektedir, $F(4,410)=2,620, p>.05$. Başka bir ifadeyle, deneklerin dua (genel) puanları, eğitim durumlarına göre anlamlı bir şekilde değişmemektedir. Dua-eğitim durumu ilişkisi, dua ölçeğinin alt boyutları açısından değerlendirildiğinde ise sadece istek ve şükür boyutunda gruplar arasında anlamlı bir fark gözlenmektedir. İstek ve şükür boyutunda, üniversite $(x=31,86)$ ile lisansüstü $(x=30,01)$ grupları arasında üniversiteliler lehine istatistiki açıdan anlamlı bir fark söz konusudur, $F(4,410)=2,944, p<, 05$. Diğer boyutlar açısından değerlendirildiğinde ise gruplar arasında anlamlı bir farklılık gözlenmemektedir.

Ancak Tablo 6 incelendiğinde eğitim seviyesi arttıkça dua ölçeği ve alt boyutlarından alınan ortalama puanların düşmekte olduğu gözlenecektir. Yani eğitim seviyesi yükseldikçe dua ölçeğinin ölçmüş olduğu dua tutum ve davranışında bir düşüş gözlenmektedir. Bu konudaki diğer çalışmaları 
incelediğimizde, Albayrak ${ }^{83}$ tarafından üniversite öğrencileri üzerinde gerçekleştirilen bir araştırmada dua tutum ve davranışı bakımından, üniversite birinci sınıf ve dördüncü sınıflar arasındaki ilişki incelenmiş; ancak eğitim seviyesi artmasına karşın gruplar arsında istatistiksel açıdan anlamı bir farklııı gözlenmemiştir. Fakat istatistiksel olarak bir fark olmamasına karşın birinci sınıfların ortalama puanı daha yüksek çıkmıştır. Bu verilerden hareketle, gruplar arasında istatistiksel olarak anlamlı farklılığın bulunmaması ya örneklem grubunun genelde benzer eğitim sistemi içerisinde yetişmiş olmalarıyla ya da dua az çok inançlı olan herkesin başvurduğu bir dini pratik olması ile eğitimin dua üzerinde bir farklılaşmaya sebebiyet vermemesi ile açıklanabilir.

\subsection{Dua ve Dinsel Eğilim Arasındaki İlişki ve Etkileşim}

$\mathrm{Bu}$ araştırmada bireylerin dua tutum ve davranışları ile dinsel eğilimleri arasında ilişki olacağı düşüncesinden hareketle, dinsel eğilimin dua tutumunda etkili olup olmadığı incelenmiştir. Bu amaçla yapılan regresyon analizinde, regresyon modeline sokulan dinsel eğilimin bağımlı değişken olarak kabul edilen dua üzerinde etkili olduğu gözlenmiştir. Dinsel eğilim bağımsız değişkenine göre dua tutumunun yordanmasına ilişkin regresyon analizi sonuçları Tablo 7'de sunulmuştur.

Tablo 7: Dua'nın Yordanmasına İlişkin Basit Regresyon Analizi Sonuçları

\begin{tabular}{|l|c|c|c|c|c|}
\hline Değişken & B & Standart Hata $_{\mathbf{B}}$ & $\mathbf{b}$ & $\mathbf{T}$ & $\mathbf{p}$ \\
\hline Sabit & 33,783 & 2,525 & - & 13,380 &, 000 \\
\hline Dinsel Eğilim & 1,389 &, 075 &, 672 & 18,420 &, 000 \\
\hline
\end{tabular}

$\mathrm{R}=, 672 \mathrm{R}^{2}=, 451$

$\mathrm{F}_{(1,413)}=339,295 \mathrm{p}=, 0000$

Dinsel eğilim değişkeniyle bağımlı değişken olan dua arasındaki korelasyonlar incelendiğinde, dinsel eğilim ile dua arasında pozitif ve orta düzeyde $(r=, 672$ $\left.r^{2}=, 451 p<, 01\right)$ anlamlı bir ilişskinin olduğu görülmektedir. Yine model olarak anlamlı olan $\left(F_{(1,413)}=339,295 p=, 000\right)$ bu modelde, dinsel eğilim, tek başına duadaki değişimin \%45'ini açıklamaktadır. Regresyon katsayılarının anlamlılığına ilişkin t-testi sonuçları incelendiğinde ise dinsel eğilim değişkeninin, dua tutumu üzerinde anlamlı bir yordayıcı olduğu görülmektedir ( $b=, 672 \mathrm{t}=18,420$ $p=, 000)$. Yani değişkenler arası ilişki ve açıklayıcılık gücünü yansıtan değerler, dinsel eğilim ve dua arasında olumlu ve açıklayıcılık gücü yüksek bir ilişki olduğunu göstermektedir. Ayrıca dua ölçeği ve alt boyutları ile dinsel eğilim ölçeği arasındaki Pearson Momentler Çarpımı korelasyonlarına da bakılmıştır. Korelasyon katsayıları ise Tablo 8'de verilmiştir.

83 Albayrak, Gençlerde Dua Psikolojisi, 115. 
Tablo 8: Dua Ölçeği ve Alt Boyutları İle Dinsel Eğilim Ölçeği Arasındaki İlişkiler (Pearson Korelasyon Testi)

\begin{tabular}{|l|c|c|c|c|c|c|}
\hline & & $\begin{array}{c}\text { Dua } \\
\text { (Genel) }\end{array}$ & $\begin{array}{c}\text { Tefekkür ve } \\
\text { Rahatlama }\end{array}$ & $\begin{array}{c}\text { İstek ve } \\
\text { Şükür }\end{array}$ & $\begin{array}{c}\text { Manevi } \\
\text { Hoşnutsuzluk }\end{array}$ & $\begin{array}{c}\text { Dinsel } \\
\text { Eğilim }\end{array}$ \\
\hline \multirow{2}{*}{$\begin{array}{l}\text { Dinsel } \\
\text { Eğilim }\end{array}$} & $\mathrm{r}$ & $\mathbf{6 7 2}^{* *}$ &, $612^{* *}$ &, $614^{* *}$ &, $396^{* *}$ & 1 \\
\cline { 2 - 7 } Ölçeği & $\mathrm{p}$ &, 000 &, 000 &, 000 &, 000 & \\
\cline { 2 - 7 } & $\mathrm{N}$ & 415 & 415 & 415 & 415 & 415 \\
\hline
\end{tabular}

** $p<0.01$

Tablo 8 incelendiğinde, dua ölçeği ve alt boyutları ile dinsel eğilim ölçeği arasında pozitif yönde anlamlı ilişkiler olduğu görülecektir. Bütün bu bulgular dinsel eğilim ile dua arasında anlamlı bir ilişki ve etkileşim olduğunu göstermektedir. Elde edilen bu bulgular daha önceki bazı çalışmalarda ulaşılan verilerle de paralellik göstermektedir. Albayrak ${ }^{84}$ tarafından üniversite öğrencileri üzerinde gerçekleştirilen bir araştırmada, deneklerin dini tutumları ile duaya ilişkin tutumları arasında yüksek düzeyde sayılabilecek anlamlı ve pozitif bir ilişki gözlenmiştir $(r=, 658 \mathrm{p}<, 01)$.

Sonuç olarak elde edilen bu veriler, dinsel eğilim puanları (iç güdümlü dindarlık) arttıkça duaya ilişkin olumlu tutumunda arttığını ortaya koymaktadır. Yani dindarlığın iç kaynaklı yöneliminin dua üzerinde olumlu etkisinin olduğu bu çalışma kapsamında ortaya konmaktadır.

\subsection{Dua ve Başa Çıkma Arasındaki İlişki ve Etkileşim}

Araştırmanın bu bölümünde, dua-başa çıkma tarzları ilişkisi bağlamında "Dua ve başa çıkma arasında nasıl bir ilişki ve etkileşim vardır?", "Dua ölçeği ve alt boyutları ile başa çıkma ve alt boyutları arasında nasıl bir ilişki vardır?" sorularına cevap aranmaktadır. Bu çerçevede başa çıkma tarzları ve alt boyutları ile dua ölçeği ve alt boyutları arasındaki Pearson Momentler Çarpımı korelasyonları incelenmiştir. Pearson korelasyon katsayıları Tablo 9'de sunulmuştur.

84 Albayrak, Gençlerde Dua Psikolojisi, 125. 
Tablo 9: Dua Ölçeği ve Alt Boyutları İle Stresle Başa Çıkma Tarzları Ölçeği ve Alt Boyutları Arasındaki İlişkiler (Pearson Korelasyon Testi)

\begin{tabular}{|c|c|c|c|c|c|c|c|}
\hline & & 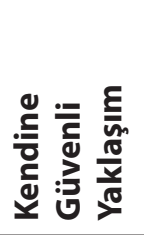 & 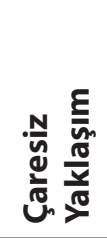 & 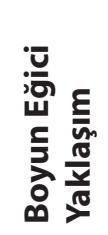 & 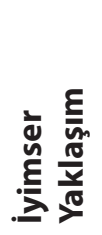 & 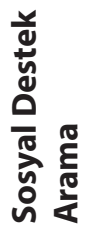 & 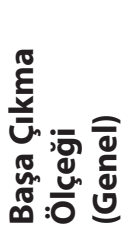 \\
\hline \multirow{3}{*}{$\begin{array}{l}\text { Tefekkür ve } \\
\text { Rahatlama }\end{array}$} & $r$ &, $339^{* *}$ & ,016 & 051 &, $281^{* *}$ & $203^{* *}$ &, $339^{* *}$ \\
\hline & $\mathrm{p}$ & ,000 & 747 & ,300 & ,000 & ,000 & ,000 \\
\hline & $\mathrm{N}$ & 415 & 415 & 415 & 415 & 415 & 415 \\
\hline \multirow{3}{*}{ İstek ve Şükür } & $r$ &, $278^{* *}$ & ,078 & ,091 &, $208^{* *}$ &, $160^{* *}$ &, $327^{* *}$ \\
\hline & $p$ & ,000 & ,113 & ,064 & ,000 & ,001 & ,000 \\
\hline & $\mathrm{N}$ & 415 & 415 & 415 & 415 & 415 & 415 \\
\hline \multirow{3}{*}{$\begin{array}{l}\text { Manevi } \\
\text { Hoşnutsuzluk }\end{array}$} & $r$ & ,310** &,$- 333^{* *}$ &,$- 163^{* *}$ &, $360^{* *}$ & $149^{* *}$ & ,047 \\
\hline & $\mathrm{p}$ & ,000 & ,000 & ,001 &, 000 & ,002 & ,344 \\
\hline & $\mathrm{N}$ & 415 & 415 & 415 & 415 & 415 & 415 \\
\hline \multirow{3}{*}{ Dua (Genel) } & $r$ &, $371^{* *}$ &,- 058 & 015 &, $328^{* *}$ & $208^{* *}$ &, $313^{* *}$ \\
\hline & $p$ & ,000 & ,235 & ,767 & ,000 & ,000 & ,000 \\
\hline & $\mathrm{N}$ & 415 & 415 & 415 & 415 & 415 & 415 \\
\hline
\end{tabular}

** $p<0.01$

Tablo 9 incelendiğinde hemen hemen her boyutta orta düzeyde anlamlı ilişkilerin olduğu gözlenmektedir. Öncelikle dua ölçeği (genel) ile başa çıkma tarzları (genel) ölçeği arasında ilişki ele alındığında, orta düzeyde pozitif anlamlı ilişki olduğu görülecektir $(r=, 313 p<, 01)$. Dua ölçeğinin alt boyutlarından olan tefekkür ve rahatlama $(r=, 339 p<, 01)$ ile istek ve şükür $(r=, 329 p<, 01)$ alt boyutu ele alındığında, başa çıkma tarzları öleceği (genel) ile aralarında pozitif yönde orta düzeyde anlamlı ilişkiler olduğu görülecektir. Yine tefekkür ve rahatlama ve istek-şükür alt boyutları ile problem odaklı başa çıkma tarzlarından olan kendine güvenli yaklaşım, iyimser yaklaşım ve sosyal destek arama alt boyutları arasında pozitif yönde orta düzeyde anlamlı ilişkiler olduğu gözlenmektedir. Bu bulgulardan hareketle, duanın pozitif etkilerini yaşayan, herhangi bir sebeple Tanrı'ya yönelerek ona yalvaran, ondan yardım dileyen, ona şükreden bireylerle; sorunlar karşısında yılmadan mücadele eden, yani aktif bir şekilde sorunların üstesinden gelmek için uğraşan katılımcıların puanları arasında pozitif yönde ilişkilerin varlığı tespit edilmiştir. Dua ölçeğinin alt boyutlarından olan manevi hoşnutsuzluk alt boyutuyla başa çıkma tarzları (genel) ölçeği 
arasında ise istatistiksel açıdan anlamlı bir ilişki tespit edilememiştir. Ancak manevi hoşnutsuzluk alt boyutu ile duygusal odaklı başa çıkma tarzlarından olan çaresiz yaklaşım $(r=-, 333 p<, 01)$ ve boyun eğici yaklaşım $(r=-, 163 p<, 01)$ arasında negatif yönde anlamlı ilişkiler gözlenirken; problem odaklı başa çıkma tarzlarından olan kendine güvenli yaklaşım $(r=, 310 p<, 01)$, iyimser yaklaşım $(r=, 360 p<, 01)$ ve sosyal destek arama $(r=, 149 p<, 01)$ alt boyutları arasında pozitif yönde anlamlı ilişkiler tespit edilmiştir. Bu veriler, sorunları ile mücadele ederken dua eden lakin duasından istediği gibi sonuç alamayan; ancak buna rağmen yılmadan devam eden deneklerin pasif başa çıkma tarzlarını (çaresiz yaklaşım, boyun eğici yaklaşım) kullanmadığını aksine aktif başa çıkma tarzlarına (kendine güvenli yaklaşım, iyimser yaklaşım, sosyal destek arama) yöneldiğini ortaya koymaktadır. Nitekim bireyin ettiği dua gerçekleşmediğinde herhangi bir olumsuzluğa sürüklenmemesi, çabasını sürdürmesi; duruma boyun eğmediğini, çaresiz bir duruma düşmediğini göstermektedir. Bu göstergeler, araştırmamızda gerçekleştirilen analizlerle de istatistiksel olarak desteklenmektedir.

\section{SONUÇ}

Bireylerin ağır şartlar altında sorunları ile baş edebilmek için dini unsurlara başvurması dini başa çıkma olarak adlandırılmaktadır. Dua en sık başvurulan ve en belirgin olan dini başa çıkma unsurlarındandır. Bu çalışma, bireylerin sorunları karşısında başvurdukları dini başa çıkma etkinliklerinden biri olan duaya odaklanmaktadır. Araştırmanın uygulamalı kısmında elde edilen veriler ve başka araştırma bulgularıyla yapılan karşılaştırmalar neticesinde şu sonuçlara ulaşılmıştır:

Uygulama sonucunda dua ile cinsiyet arasında, manevi hoşnutsuzluk alt boyutu dışında istatistiksel olarak anlamlı bir fark gözlenmemiştir. Her ne kadar kadınların dua ölçeği ve alt boyutlarından almış oldukları ortalamalar erkeklere göre daha yüksek olmasına rağmen istatistiksel olarak yalnızca bir boyutta anlamlı farklılık hesaplanmıştır. Manevi hoşnutsuzluk alt boyutunda ise erkekler ve kadınlar arasında erkekler lehine anlamlı bir farklılık gözlenmiştir.

Yapılan analizler neticesinde, örneklem grubunun dua ölçeği ortalama puanları arasında yaş dönemleri bakımından anlamlı bir fark olmadığı tespit edilmiştir. Dua-yaş dönemleri ilişkisi, dua ölçeğinin alt boyutları açısından değerlendirildiğinde ise gruplar arasında istatistiksel olarak anlamlı bir farklılık olmadığı tespit edilmiştir.

Genel olarak dua ölçeği ortalama puanlarına göre, bekârlar ve evliler arasında anlamlı bir farklılık tespit edilememekle birlikte dua ölçeği ve alt boyutlarında, evlilerin ortalama puanlarının bekârlara göre daha yüksek olduğu tespit edilmiştir.

Dua ve sosyal çevre ilişkisi bakımından, yaşamının çoğunu kırsal kesimde geçirenlerin ortalamalarının, yaşamının çoğunu kentlerde geçirenlere göre daha 
yüksek olduğu tespit edilmesine karşın dua düzeyleri bakımından sosyal çevre grupları arasında istatistiksel açıdan anlamlı bir farklılık görülmemiştir.

Gelir durumu-dua ilişki incelendiğinde, gelir durumu çok iyi ve iyi olan deneklerin dua ölçeğinden aldıkları puanlar, gelir durumu orta ve düşük olan deneklerin dua ölçeğinden aldıkları puanlara göre daha yüksektir. Ancak ortalama puanlar dikkate alındığında, dua ölçeğinden alınan puanlar gelir durumuna göre anlamlı bir farklılık göstermemektedir.

Dua ve eğitim durumu ilişkisi incelendiğinde, deneklerin dua (genel) puanlarının, eğitim durumlarına göre anlamlı bir şekilde değişmediği görülmüştür. Dua-eğitim durumu ilişkisi, dua ölçeği alt boyutları açısından değerlendirildiğinde ise sadece istek ve şükür boyutunda gruplar arasında anlamlı bir fark gözlenmektedir. İstek ve şükür boyutunda, üniversite ile lisansüstü gurupları arasında üniversiteliler lehine istatistiki açıdan anlamlı bir fark tespit edilmiştir. Ancak eğitim seviyesi arttıkça dua ölçeği ve alt boyutlarından alınan ortalama puanların düşmekte olduğu gözlenmiştir.

Regresyon analizi ve çoklu kolerasyon tekniği ile yapılan analizler çerçevesinde dua ve dinsel eğilim arasındaki ilişki ve etkileşim incelendiğinde, dinsel eğilim ile dua arasında pozitif ve orta düzeyde anlamlı bir ilişkinin varlığı tespit edilmiştir. Dinsel eğilim duadaki değişimin \%45'ini açıklamıştır. Bu veriler, dinsel eğilimin dua üzerinde anlamlı bir yordayıcı olduğunu göstermektedir. Değişkenler arası ilişki ve açıklayıcılık gücünü gösteren değerler, dinsel eğilim ve dua arasında olumlu ve açıklayıcılık gücü yüksek bir ilişki olduğunu ortaya koymuştur.

Son olarak, çoklu kolerasyon tekniği ile yapılan analizler çerçevesinde dua ve başa çıkma tarzları arasındaki ilişki incelendiğinde, dua ve başa çıkma tarzları ölçeği ve alt boyutları arasında genel olarak orta düzeyde, pozitif anlamlı ilişkilerin olduğu tespit edilmiştir. Bu veriler bir tür uygunluk geçerliliği açısından da duanın bir başa çıkma mekanizması olduğunu açık bir şekilde ortaya koymuştur.

\section{KAYNAKÇA}

Albayrak, Ahmet. Gençlerde Dua Psikolojisi. İstanbul: Düşünce Kitabevi Yayınları, 2013.

Altunışık, Remzi - Coşkun, Recai - Bayraktaroğlu, Serkan - Yıldırım, Engin. Sosyal Bilimlerde Araştırma Yöntemleri SPSS Uygulamalı. 7. Baskı. Sakarya: Sakarya Yayıncılık, 2012.

Argyle, Michael "ibadet ve Dua". Trc. Mustafa Koç. Erciyes Üniversitesi Sosyal Bilimler Enstitüsü Dergisi 2/21 (2006): 317-338.

Argyle, Michael. Psychology and Religion: An Introduction. London: Routledge, 2005.

Arıcı, Asude. Ergenlerde Dini Başa Çıkma Yöntemi Olarak Dua. Yüksek Lisans Tezi, Uludağ Üniversitesi, 2005. 
Ayten, Ali. Prososyal Davranışlarda Dindarlık ve Empatinin Rolü. Doktora Tezi, Marmara Üniversitesi, 2009.

Ayten, Ali. Tanrı'ya Sığınmak Dini Başa Çıkma Üzerine Psiko-sosyal Bir Araştırma. İstanbul: İz Yayıncilık, 2012.

Banziger, S. - Van Uden, M. - Janssen, J. "Praying and Coping: The Relation Between Varieties of Praying and Religious Coping Styles". Mental Health Religion \& Culture 11/1 (2008): 101-108.

Bebek, Adil. Din ve Düşünce Açısından Dua. İstanbul: Rağbet Yayınları, 1998.

Bjorck, J. P. - Thurman, J. W. "Negative Life Events, Patterns of Positive and Negative Religious Coping, and Psychological Functioning". Journal for the Scientific Study of Religion 46/2 (2007): 159-167.

Brown, L. B. "The Structure of Religious Belief". Journal for the Scientific Study of Religion" 5 (1966): 259-272.

Carrel, Alexis. Duâ. Trc. M. Alper Yücetürk. İstanbul: Yağmur Yayınevi, 1961.

Cilacı, Osman "Duâ". Türkiye Diyanet Vakfı İslâm Ansiklopedisi. 9: 529-530. İstanbul: TDV Yayınları, 1994.

Cüceloğlu, Doğan. Insan ve Davranışı Psikolojinin Temel Kavramları. İstanbul: Remzi Kitapevi, 2010.

Dağcı, Abdullah. "Amaçsal Açıdan Dua Türleri: Din Psikolojisi Bağlamında Tümevarımsal Bir Yaklaşım Denemesi". Eskişehir Osmangazi Üniversitesi Illahiyat Fakültesi Dergisi 5/8 (2018): 87-120.

Doğan, M. Duanın Psikolojik ve Psikoterapik Etkileri. Yüksek Lisans Tezi, Uludağ Üniversitesi, 1997.

Douglas, Steere V., Duâ ve ibadet. İstanbul: Akın Basımevi, 1941.

Ekşi, Halil. Başaçıkma, Dini Başaçıkma ve Ruh Sağlığı Arasındaki Iliş̧i Üzerine Bir Araştırma Eğitim, Illahiyat ve Mühendislik Fakültesi Öğrencilerinin Karşılaştırılması. Doktora Tezi, Uludağ Üniveristesi, 2001.

Ekşi, Halil. "Kişilik ve Başaçıkma: Başaçıkma Tarzlarının Durumsal ve Eğlemsel Boyutları Üzerine Çok Yönlü Bir Araştırma". Kuram ve Uygulamada Eğitim Bilimleri 4/1 (2004): 81-98.

Eryılmaz, Ali. "Bir Yaşam Dönemi Olarak Yetişkinlik: Tanımı, Ölçütleri ve Kuramları". Yetişkinlik ve Yaşlılık Gelişimi ve Psikolojisi. Ed. Hasan Bacanlı - Şerife Terzi. 49-85. İstanbul: Açılım Kitap, 2012.

Fîrûzâbâdî, Muḥammed b. Ya'kûub. "D’av". el-Ḳâmûsu'l-muhît. 4:321. Mısır: Matbaatu'IEmîrîyye, 1979.

Gashi, Feim. "Dua ve Hayat Memnuniyeti Üzerine Karşılaştırmalı Bir Araştırma (Kırklareli Üniversitesi Illahiyat Fakültesi ve Fen-Edebiyat Fakültesi Öğrencileri Örneği)" Uludağ Üniversitesi Illahiyat Fakültesi Dergisi 25/2 (2016): 1-29.

Gazâlî. İhyâu ulûmi'd-dîn. Trc. Ahmet Serdaroğlu. 1 Cilt. İstanbul: Bedir Yayınevi, 1989.

Genç, F. Kemoterapi Alan Akciğer Kanserli Hastalarda Görülen Semptomlar ve Başa Çıkma Tarzları. Yüksek Lisans Tezi, Atatürk Üniversitesi, 2005. 
Gündüz, Şinasi. Din ve Inanç Sözlüğü. Ankara: Vadi Yayınları, 1998.

Hayta, Akif. "ibadetler ve Ruh Sağlığı (Dini Pratikler ile Psiko-Sosyal Uyum Arasındaki iliş̧ki Üzerine Bir İnceleme)". Gençlik Din ve Değerler Eğitimi. Ed. Hayati Hökelekli. 137-180. İstanbul: Dem Yayınları, 2006.

Heiler, F. Prayer A Study in the History and Psychology of Religion. New York: Oxford University Press, 1932.

Horozcu, Ümit. Din Psikolojisi Açısından Dünyevi İstek Duaları. Doktora Tezi, İstanbul Üniversitesi, 2010.

Hökelekli, Hayati. Din Psikolojisi. 10. Baskı. Ankara: TDV Yayınları, 2013.

Hökelekli, Hayati. Ergenlik Çağı Gençlerin Dini Gelişimi. 1983.

Hökelekli, Hayati. İslam Psikolojisi Yazıları. İstanbul: Dem Yayınları, 2009.

İbn Fâris. "D'av". Mu'cemu mekâyîsu'l-lugia. Thk. Abdusselâm Muhammed Harun. 2:279. Beyrut: Daru'l-Fikr, 1979.

İbn Manzûr. "D’av". Lisânu'I-Arab. 14:257-263 . Beyrut: Dâru Sâdr, ts.

İkbal, Muhammed. İslam'da Dini Düşüncenin Yeniden Inşâsı. Trc. Rahim Acar. İstanbul: Timaş Yayınları, 2013.

İșfahânî, Râgıb. "D'av". el-Müfredât fî garîbi'l-Kur'ân. Thk. Muhammed Seyyid Keylânî. 1:169-170. Beyrut: Daru'l-Marife, ts.

Izutsu, Toshihiko. Kur'ân'da Allah ve Insan. Trc. Süleyman Ateş. Ankara: Ankara Üniversitesi Basımevi, 1975.

James, William. The Varieties of Religious Exerience: A Study in Human Nature. London: Fontana Library, 1962.

Karacoşkun, Doğan. Okul Öncessi Dönem Çocuklarında Dua, Cumhuriyet Üniversitesi Illahiyat Fakültesi Dergisi, 9/1 (2005): 101-124.

Karagöz, İsmail. "Duanın Anlamı ve Önemi, Çeşitleri, Usulü, Âdâbı ve İnsan Hayatına Etkisi”. Dualar. Ed. İsmail Karagöz. 21-134. Ankara: Diyanet İşleri Başkanlığı Yayınları, 2011.

Kayıklık, Hasan. Dini Yaşayış Biçimleri: Psikolojik Temelleri Açısından Bir Değerlendirme. Doktora Tezi, Dokuz Eylül Üniversitesi, 2000.

Kılıç, Ahmet Faruk. "Psiko-Sosyal Faktörler Açısından Atatürk ve Din". Sakarya Üniversitesi Ilahiyat Fakültesi Dergisi 2 (2000): 239-271.

Kimter, Nurten. “Dini İnanç, İbadet ve Dua'nın Umutsuzlukla İlişkisi Üzerine Bir Araştırma (Üniversite Öğrencileri Üzerine)". Gençlik Din ve Değerler Psikolojisi. Ed. Hayati Hökelekli. 217-250. İstanbul: Dem Yayınları, 2006.

Kirkpatrick, Lee A. "Attachmet Theory and Religious Experience". Handbook of Religious Experience. Ed. Ralph W. Hood. 446-475. Birmingham: Religious Education Press, 1995.

Koening, Harold G. - Pargament, Kenneth I. - Nielsen, Julie. "Religious Coping and Health Status in Medically III Hospitalized Older Adults". The Journal of Nervous \& Mental Disease 186/9 (1998): 513-521.

Kula, Naci. Bedensel Engellilik ve Dini Başa Çıkma. İstanbul: Dem Yayınları, 2005.

Kula, Naci. "Deprem ve Dini Başa Çıkma". Gazi Üniversitesi Çorum Ilahiyat Fakültesi Dergisi 1 (2002): 234-255. 
Kula, Naci. "Gençlerde Istırap Tecrübesine Bağlı Dini Krizle Başa Çıkmaya Yönelik Öneriler”. Gençlik Dönemi ve Eğitimi - II. 103-131. İstanbul: Ensar Yayınları, 2003.

Küçükcan, Talip - Köse, Ali. Doğal Afetler ve Din Marmara Depremi Üzerine Psiko-Sosyolojik Bir Inceleme. Ankara: Türkiye Diyanet Vakfı Yayınları, 2006.

Lazarus, Richard S. - Folkman, Susan. Stres, Appraisal and Coping. New York: Springer, 1984.

Lazarus, Richard S. - Lazarus, Bernice N. Coping with Aging. New York: Oxford University Press, 2006.

Lewis, C. A. - Maltby, J. - Day, L. "Religious Orientation, Religious Coping and Happiness Among UK Adults". Personality and Individual Differences. 38 (2005): 1193-1202.

Marinier, Pierre. Dua Üzerine Düşünceler (Psikofizyolojik sebepleri ve sonuçları). Trc. Sadık Kılıç. İzmir: Nil Yayınları, 1991.

Matsumoto, David. The Cambridge Dictionary of Psychology. New York: Cambridge University Press, 2009.

Onur, Bekir. Gelişim Psikolojisi Yetişkinlik-Yaşııık-Ölüm. Ankara: İmge Kitabevi, 2011.

Pargament, Kenneth I. "Acı ve Tatlı: Dindarlığın Bedelleri ve Faydaları Üzerine Bir Değerlendirme". Trc. Ali Ulvi Mehmedoğlu. Çukurova Üniversitesi Illahiyat Fakültesi Dergisi 5/1 (2005): 279-313.

Pargament, Kenneth I. "'Tanrım Bana Yardım Et' Din Psikolojisi Açısından Başa Çıkmanın Teorik Çatısına Doğru". Trc. Ahmet Albayrak. Tabula Rasa 9 (2003): 207-238.

Pargament, Kenneth I. The Psychology of Religion and Coping Theory, Research, Practice. New York: The Guilford Press, 1997.

Pargament, Kenneth I. - Koening, Harold G. - Tarakeshwar, N. - Hah, J. "Religious Coping Methods as Predictors of Psychological, Physical ad Spiritual Outcomes among Medically ill Elderly Patients: A Two-Year Longitudinal Study". Journal of Health Psychology 9/6 (2004): 713-730.

Pargament, Kenneth I. - Park, Crystal L. "In Times of Stress: The Religion-Coping Connection". The Psychology of Religion: Theoretical Approaches. Ed. B. Spilka - D. N. McIntosh. 43-53. Boulder: Westview Press, 1997.

Pargament, Kenneth I. - Smith, B. W. - Koening, H. G. - Perez, L. “Patterns of Positive and Negative Religious Coping with Major Life Stressors". Journal for the Scientific Study of Religion 37/4 (1998): 710-724.

Pargament, Kenneth I. - Van Haitsna, K. S. - Ensing, D. S. "Religion and Coping". Aging, Spirituality, and Religion: A Handbook. Ed. M. Kimble - S. Mcfadden - J. Ellor - J. Seeber. Minneapolis: Fortress Press, 1995.

Parladır, Selâhattin. "Dua: Varlığın Özü, İbadetin Ruhu". İslam'a Giriş. 328-345. Ankara: Diyanet İşleri Başkanlığı Yayınları, 2007.

Peker, Hüseyin. Din Psikolojisi. 7. Baskı. İstanbul: Çamlıca Yayınları, 2011.

Phillips, D. Z. The Concept of Prayer. London: Routledge and Kegan Paul, 1965.

Poloma, M. M. - Pendleton, B. F. "Religious Experiences, Evangelism, and Institutional Growth within the Asseblies of God". Journal for the Scientific Study of Religion 28 (1989): 415-431. 
Smith, E. E. - Nolen-Hoeksema, S. - Fredrickson, B. L. - Loftus, G. R. Atkinson \& Hilgard Psikolojiye Giriş. Trc. Ö. Öncül - D. Ferhatoğlu. 14. Baskı. Ankara: Arkadaş Yayınevi, 2012.

Şahin, Nesrin H. - Durak, Ayşegül. "Stresle Başaçıkma Tarzları Ölçeği: Üniversite Öğrencileri İçin Uyarlanması". Türk Psikoloji Dergisi 10/34 (1995): 56-73.

Şeriati, Ali. Dua. 2. Baskı. Ankara: Fecr Yayınları, 2010.

Tekin, F. Stresle Başa Çıkmada Din Eğitiminin Rolü. Doktora Tezi, Selçuk Üniversitesi, 2005.

Topuz, İlhan. Dini Gelişim Seviyeleri ile Dini Başaçıkma Tutumları Arasındaki Ilişsi Üzerine Bir Araştırma. Doktora Tezi, Uludağ Üniversitesi, 2003.

Vergote, Antonie. Din, Inanç ve Inançsızlık. Trc. Veysel Uysal. İstanbul: Marmara Üniversitesi İlahiyat Fakültesi Vakfı Yayınları, 1999.

Wulff, David M. Psychology of Religion Classic and Contemporary. New York: John Wiley \& Sons, 1991.

Yaman, Erkan - Temiz, Yunus E. "Dua Ölçeği'nin Geliştirilmesi: Geçerlik ve Güvenirlik Çalışması". Değerler Eğitimi Dergisi 12/28 (2014): 193-219.

Yaparel, Recep. “Depresyon ve Dini İnançlar İle Tabiatüstü Nedensel Yüklemeler Arasındaki İlişkiler". Dokuz Eylül Üniversitesi Ilahiyat Fakültesi Dergisi 8 (1994): 275-299.

Yaparel, Recep. Yirmi-Kırk Yaşlar Arası kişilerde Dini Hayat Ile Psiko-Sosyal Uyum Arasındaki illişki Üzerine Bir Araştırma. Doktora Tezi, Ankara Üniversitesi, 1987.

Yapıcı, Asım. "Güdü ve İçerik Açısından Çocuk Duaları ve Dualara Yansıyan Sorunlar". Çukurova üniversitesi İlahiyat Fakültesi Dergisi 5/2 (2005): 57-93.

Zebîdî, Muhammed Murtazâa. "D'av". Tâcü'I-arûs min Cevâhiri'l-kâmûs. 38:46-47. Kuveyt: Turâsu'l-Arabi, 1965. 